\title{
Domesticating International Obligations: How to Ensure U.S. Compliance with the Vienna Convention on Consular Relations
}

\author{
Sarah M. Ray†
}

\section{TABLE OF Contents}

Introduction

I. VCCR: Creating Rights for Foreign Nationals

A. Drafting, Ratification, and Implementation of the VCCR ........ I 734

B. History of VCCR Claims in U.S. Courts ............................... I 736

1. Individual Rights Under the VCCR?.............................. 1737

2. Individual Remedy for Violations of the VCCR? ............. 1740

C. The Breard and LaGrand Cases in U.S. Courts ...................... 1742

1. Breard v. Greene ........................................................... 1742

2. The LaGrand Cases.......................................................... 1744

II. The ICJ Decision in LaGrand: Defining the Rights of Foreign

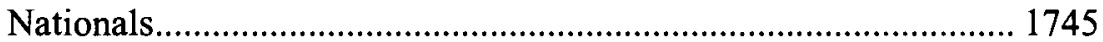

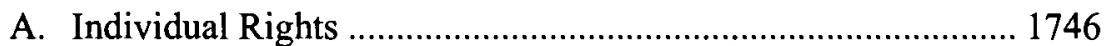

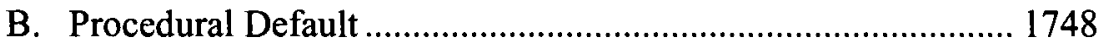

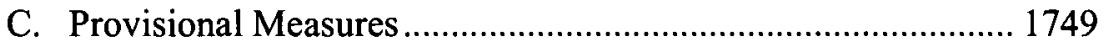

D. Future Compliance............................................................... 1751

III. Impact of the ICJ's LaGrand Decision on U.S. Courts................... 1753

A. Disappointing Judicial Response in the United States After

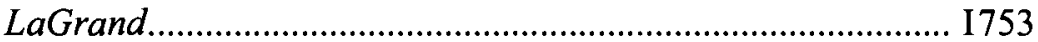

B. A Glimmer of Hope: The Valdez Case ................................ 1755

IV. The Aftermath of LaGrand: Mexico's Challenge to the United States

Copyright $\odot 2003$ California Law Review, Inc. California Law Review, Inc. (CLR) is a California nonprofit corporation. CLR and the authors are solely responsible for the content of their publications.

$\dagger \quad$ J.D., School of Law, University of California, Berkeley (Boalt Hall), 2003. I would like to recognize the professional and capable work of the California Law Review. Any errors that remain are my own. Thanks also go to Charles Weisselberg and Elisabeth Semel for their example and inspiration, Jeff Bleich for his astute advice and encouragement, and Andrew Salverda and my family for their love and support. 
A. Mexico Turns to the ICJ ......................................................... 1758

1. Mexico's Case Againsst the United States .......................... 1759

2. The Positions of the United States and Mexico

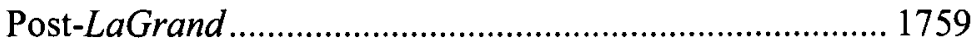

3. The ICJ Orders Provisional Measures................................ 1762

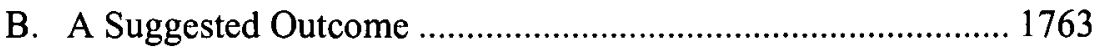

C. Likely U.S. Intransigence ….................................................. 1765

V. The Future of the Rights of Foreign Nationals: How to Ensure U.S. Compliance with the VCCR ................................................ 1766

A. The Authority of International Law ........................................ 1766

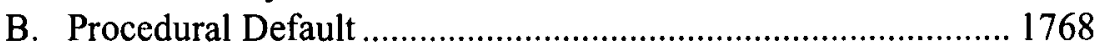

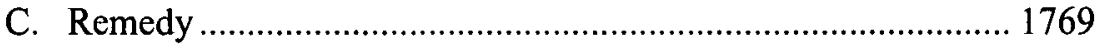

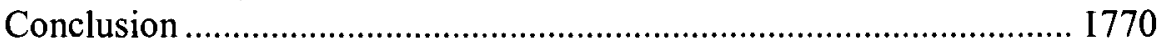




\title{
Domesticating International Obligations: How to Ensure U.S. Compliance with the Vienna Convention on Consular Relations
}

\author{
Sarah M. Ray
}

\section{INTRODUCTION}

On June 27, 2001, the International Court of Justice (ICJ) ${ }^{1}$ held that the United States had violated obligations to Germany ${ }^{2}$ under the Vienna Convention on Consular Relations (VCCR). ${ }^{3}$ The ICJ also held that the United States breached its obligations under Article $36^{4}$ of the VCCR to the LaGrand brothers, ${ }^{5}$ citizens of Germany convicted of first-degree murder and sentenced to death in Arizona. ${ }^{6}$ Finally, the ICJ decided "for the first time in its history"7 that provisional measures indicated under Article 41 of its charter are legally binding, and thus, that an $1 \mathrm{CJ}$ order to stay the execution of Walter LaGrand pending a full hearing of the case was binding on

1. The U.N. Charter established the ICJ as the "the principal judicial organization of the United Nations." U.N. ChARTER art. 92. The ICJ has jurisdiction to settle certain disputes between states and may provide advisory opinions at the request of authorizcd bodies. Statute of the International Court of Justice, June 26, 1945, arts. 36, 65, 59 Stat. 1055, integrated in U.N. CHARTER art. 92. When a dispute between states arises out of the application of a trcaty, jurisdiction will be proper if that treaty contained a provision referring such disputes to the ICJ. Id. at art. 36(1). See also International Court of Justice, General Information-The Court at a Glance, at http://www.icj-cij.org/icjwww/igeneralinformation /icjgnnot.html.

2. LaGrand Case (F.R.G. v. U.S.) at para. 128 (June 27, 2001), http://www.icj-cij.org /icjwww/idocket/igus/igusframe.htm.

3. Vienna Convention on Consular Relations, Apr. 24, 1963, U.N. Conf. on Consular Relations, 2 Official Records 175, U.N. Doc. A/CONF.25/12, Annex, 21 U.S.T. 77, 596 U.N.T.S. 261 [hereinafter VCCR].

4. Artiele 36 of the VCCR, entitled "Communication and contaet with the nationals of the sending State," provides that a national of a member state arrested or detained in another member state has the right of notification and access to his consul "without delay." Id. at art. 36(1).

5. LaGrand, at para. 128.

6. See State v. LaGrand (Walter), 734 P.2d 563 (Ariz. 1987); State v. LaGrand (Karl), 733 P.2d 1066 (Ariz. 1987).

7. Press Release 2001/16, International Court of Justice, The Court Finds That the United States Has Breached Its Obligations to Germany and to the LaGrand Brothers Under the Vienna Convention on Consular Relations (June 27, 2001), http:/www.icj-cij.org/icjwww/ipresscom/ipress2001 /ipresscom2001-16_20010627.htm. 
the United States. ${ }^{8}$ Though the lengthy decision addressed and settled many open questions with regard to member states' obligations under the VCCR, it was labor in vain for the LaGrand brothers. As of the date of the ICJ's final judgment in LaGrand, Arizona had already executed both brothers.'

That Germany pursued its ease to final judgment despite the executions, ${ }^{10}$ and that the ICJ issued such a thorough and decisive opinion, ${ }^{11}$ are evidence of the continuing relevance of this issue to the international community. The circumstances that brought the LaGrand case to the courts were not unusual, and this was not the only time that the ICJ or the U.S. Supreme Court adjudicated claims of VCCR violations by the United States. ${ }^{12}$ However, the ICJ decision directly contradicted several positions of the U.S. Department of Justice and the U.S. Supreme Court that U.S. state and federal courts had consistently relied on to avoid providing a remedy for these ongoing domestic violations. The ICJ is the body charged with final interpretation of certain U.N. treaties, including the VCCR. ${ }^{13}$ However, nearly two years after the LaGrand decision was decided, it is clear that U.S. courts continue to cling to infirm domestic precedent in the absence of a contrary government mandate or Supreme Court ruling. ${ }^{14}$

And, apparently, the international community is paying close attention to U.S. domestic decisions on VCCR claims. In early 2003, Mexico responded to the continuing VCCR enforcement problems in the United

8. See LaGrand, at para. 77 (concluding that Article 36 "creates individual rights" and that those rights "were violated in the present case"); id. at para. 109 (holding that "orders on provisional measures under Article 41 have binding effect").

9. Karl LaGrand was executed in Arizona on February 24, 1999. Walter LaGrand was executed in Arizona on March 3, 1999, after the U.S. Supreme Court refused to enforce compliance with the provisional measures indicated by the ICJ. See LaGrand, at paras. 26-34; see also Federal Republic of Germany v. United States, 526 U.S. 111 (1999).

10. In contrast, Paraguay abandoned a similar case pending before the $\mathrm{ICJ}$ after one of its citizens was executed in Virginia. Press Communiqué 98/36, International Court of Justice, Case Removed from the Court's List at the Request of Paraguay (Nov. 11, 1998), http:/www.icj-cij.org/icjwww/ idocket/ipaus/ipausframe.htm.

11. The ICJ decision was fourteen to one as to individual rights and the U.S. violations and thirteen to two as to the binding nature of provisional measures. LaGrand, at para. 128.

12. See Concerning the Vienna Convention on Consular Relations (Para. v. U.S.), 1998 I.C.J. 248 (Apr. 9); Breard v. Greene, 523 U.S. 371 (1998).

13. See Statute of the International Court of Justice, supra note 1, at arts. 36, 65; Vienna Convention on Consular Relations, Optional Protocol Concerning the Compulsory Settlement of Disputes, Apr. 24, 1963, 21 U.S.T. 325, 596 U.N.T.S. 487, available at http:/www.un.org/law/ilc /texts/consul.htm [hereinafter VCCR Optional Protocol] (expressing the intent of parties to the VCCR "to resort in all matters concerning them in respect of any dispute arising out of the interpretation or application of the Convention to the compulsory jurisdiction of the International Court of Justice"). Amnesty International hailed the ICJ decision as "historic," requiring "full compliance by the United States." News Release, Amnesty Int'l, No More Excuscs: The USA Must Obey International Court Decision on Prisoners' Rights (June 27, 2001), http://web.amnesty.org/library/Index /ENGAMR510982001.

14. See, e.g., United States v. Emuegbunam, 268 F.3d 377, 392 (6th Cir. 2001) (concluding "that the [VCCR] does not create in a detained foreign national a right of consular access"); see also infra Part III. 
States by filing its own challenge to U.S. practices in the ICJ. ${ }^{15}$ The application, filed on behalf of fifty-four Mexican nationals sentenced to death in the United States, alleged "irreconcilable views" between Mexico and the United States as to both the scope of the VCCR and the obligations under it. ${ }^{16}$ Accordingly, Mexico sought to "establish definitively" its rights under the VCCR, "as authoritatively interpreted by [the ICJ] in LaGrand."17 Finding itself once again before the ICJ on charges of violating its treaty obligations, the U.S. government is now compelled to justify U.S. actions to the international community in the context of LaGrand.

This Comment details the U.S. response to LaGrand, both in its courts and by the federal government, and also explores the difficult stance in which these aetions have placed the ICJ with regard to Mexico's recent application. It urges that, contrary to some scholarly opinion, ${ }^{18}$ the governmental body best suited to acknowledge the ICJ decision and enforce domestic compliance with its mandates is the U.S. Supreme Court.

Part I of this Comment sets out the judicial history of the claims raised under the VCCR by foreign defendants in U.S. courts, including the circumstances of the U.S. cases that led to the ICJ decision of June 2001. Part II analyzes the LaGrand decision in the ICJ, specifically assessing each of Germany's claims against the United States, the argnments put forth by the United States against such claims, and the reasoning of the ICJ in reaching its decision. With a view to the most recent legal history of VCCR claims in the United States, Part III discusses the repercussions the LaGrand decision has had on U.S. jurisprudence in this area and concludes that, without better judicial guidance, U.S. courts will continue to ignore or misinterpret the LaGrand decision. Here, this Comment takes particular stock of pending VCCR cases in U.S. courts, including a recent Oklahoma case ${ }^{19}$ in which a defendant was granted a reprieve, at least in part, on the basis of the ICJ decision. Part IV then examines Mexico's current application in the ICJ and the arguments posited by the United States in response to Mexico's request for provisional relief. Despite the recent grant of provisional measures, this Part suggests that the U.S. position, though flawed, puts the ICJ in a difficult position going forward. Though Part IV suggests

15. See Application Instituting Proccedings, Avena and Other Mexican Nationals (Mex. v. U.S.) (Jan. 9, 2003) (General List No. 128), http://www.icj-cij.org/icjwww/idocket/imus/imusorder /imus_iapplication_20030109.pdf.

16. Id. at para. 5 .

17. Id.

18. See Erik G. Luna \& Douglas J. Sylvester, Beyond Breard, 17 Berkeley J. INT'L L. 147, 150 (1999) (arguing that the clevation of Treaty rights to the status of constitutional liberties will come, if at all, "by political action rather than judicial activism"); see also Molora Vadnais, A Diplomatic Morass: An Argument Against Judicial Involvement in Article 36 of the Vienna Convention on Consular Relations, 47 UCLA L. Rev. 307 (1999).

19. See John Greiner, Mexican National Granted Indefinite Stay of Execution, DAlLY OKLahoman, Sept. 11, 2001, at 1A. 
an ICJ decision on the merits that would further clarify LaGrand without causing damage to the legitimacy of the ICJ, this Comment ultimately argues in Part V that the only way to ensure full compliance by the United States with its international legal obligations under the VCCR is through a definitive binding judgment of the U.S. Supreme Court.

\section{I}

VCCR: Creating Rights for Foreign Nationals

\section{A. Drafting, Ratification, and Implementation of the VCCR}

In 1963, the United States signed the Vienna Convention on Consular Relations, a United Nations treaty designed to codify existing international customary law with regard to consular "relations, privileges and immunities." ${ }^{20}$ Though the preamble to the treaty specifically states that "the purpose of such privileges and immunities is not to benefit individuals but to ensure the efficient performance of functions by consular posts on behalf of their respective States,"21 Article 36(1)(b) nonetheless provides that an individual foreign national arrested in a signatory state has the right to free communication with and access to his consulate. ${ }^{22}$ During the drafting process of Article 36, a debate arose as to whether consular notification should be mandatory or at the discretion of the detainee. ${ }^{23}$ The United Kingdom, for one, opposed giving its nationals a choice in consular notification, not to deprive them of the right but specifically to protect that right from "abuses and misunderstanding." 24 The U.K. delegate warned that predicating consular notification upon the detainee's request could "make the provisions of article 36 ineffective because the person arrested might not be aware of his rights." ${ }^{25}$ This prescient observation gave rise to the notice requirement of Article 36(1)(b): "[t]he said authorities shall inform the person concerned without delay of his rights" to contact his consul. ${ }^{26}$

20. VCCR, supra note 3 , at pmbl.

21. Id.

22. The text of Article 36(1)(b) of the VCCR provides:

If [the detainee] so requests, the competent authorities of the receiving State shall, without delay, inform the consular post of the sending State if, within its consular district, a national of that State is arrested or committed to prison or to custody pending trial or is detained in any other manner. Any communication addressed to the consular post by the person arrested, in prison, custody or detention shall also be forwarded by the said authorities without delay. The said authorities shall inform the person concerned without delay of his rights under this sub-paragraph.

VCCR, supra note 3 , at art. 36(1)(b).

23. For a discussion of this debate, specifically, and the "tortuous and checkered background" of Article 36, generally, see Luke T. Lee, Vienna Convention on Consular Relations 107, 16-17 (1966).

24. U.N. Conf. on Consular Relations, 1 Official Records, 20th plen. mtg. at 83, U.N. Doc. A/CONF.25/16, U.N. Sales No. 63.X.2 (1963).

25. Id. at 83-84.

26. VCCR, supra note 3, at art. 36(1)(b). 
In 1969 , the U.S. Senate ratified the VCCR. ${ }^{27}$ The six-year delay between signing and ratifying the VCCR was largely due to a concern that, as a multilateral treaty subject to approval by many nations, the VCCR represented a watered-down version of protection for foreign nationals compared to the bilateral treaties to which the United States was already a party. ${ }^{28}$ This unease highlighted U.S. officials' belief that consular notification afforded significant protections to U.S. citizens detained in foreign countries. Ratification of the VCCR came only after it was clarified that the VCCR would supplement, not displace, existing and future bilateral treaties regarding consular relations. ${ }^{29}$

Under the U.S. Constitution, a treaty is incorporated into U.S. law. ${ }^{30}$ The Supremacy Clause provides:

This Constitution, and the Laws of the United States which shall be made in Pursuance thereof; and all Treaties made, or which shall be made, under the Authority of the United States, shall be the supreme Law of the Land; and the Judges in every State shall be bound thereby, any Thing in the Constitution or Laws of any State to the Contrary notwithstanding. ${ }^{31}$

Upon ratification, the VCCR thus took its place as "[S]upreme Law of the Land," on par with federal legislation and superior to state law and policy. ${ }^{32}$ Therefore, the terms of the VCCR apply to the conduct of state and federal law enforcement, must be enforced in state and federal courts, and take precedence over any conflicting state law.

27. See 115 CONG. REC. S30,953, S30,997 (daily ed. Oct. 22, 1969).

28. See id. Senator J. William Fulbright, Chairman of the Senate Foreign Relations Committee, reported:

The committee was told that the delay was largely due to a disagreement within the executive branch between those who advocated continuing the traditional U.S. bilateral approach to consular conventions or following the multilateral one represented by the [VCCR].... The multilateral versus bilateral argument points up a basic characteristic of the [VCCR]. It embodies those standards upon which the 92 nations representcd at the conference could agree. In many ways, these are minimum standards-not as high as those embodied in our bilateral treaties.

Id. at $\mathrm{S} 30,953$ (statement of Sen. Fulbright).

29. Id. at $\mathrm{S} 30,953$ (statement of Sen. Fulbright).

30. U.S. CONST. art. V1, $\$ 2$.

31. Id.

32. See United States v. Pink, 315 U.S. 203, 230-31 (1942) ("[S]tate law must yield when it is inconsistent with, or impairs the policy or provisions of, a treaty or of an international compaet or agreement."); Hines v. Davidowitz, 312 U.S. 52, 62-63 (1941) (holding that a federal treaty or statute "establish[ing] rules and rcgulations touching the rights, privileges, obligations or burdens of aliens as such, ... is the supreme law of the land[,] .. [and n]o state can add to or take from the force and effect" thcreof); Foster v. Neilson, 27 U.S. 253, 314 (1829) (noting that a treaty is "equivalent to an act of the legislature, whenever it operates ... without the aid of any legislative provision"), overruled in part on other grounds by United States v. Percheman, 32 U.S. 51, 89 (1833); see also S. EXEC. ReP. No. 91-9, app. at 18 (1969) (statement of J. Edward Lyerly, Deputy Legal Adviser for Administration) ("[T]o the extent that there are conflicts with Federal legislation or State laws," the VCCR governs.). 
When the executive branch submitted the VCCR to the Senate for ratification, the report called the treaty "entirely self-executive" and indicated that it did not "require any implementing or complementary legislation" to become effective. ${ }^{33}$ Recognizing the increased burden put on law enforcement, however, the federal government promulgated new procedural rules for both the FBI and the INS in compliance with the notice provision of Article $36(1)(b){ }^{34}$

\section{B. History of VCCR Claims in U.S. Courts}

Although the United States evinced enormous concern that U.S. nationals receive protection under the VCCR when detained abroad, for many years foreign nationals arrested in the United States were rarely notified of their right to consular assistance. These violations had the potential to prejudice significantly the individuals affected. In many cases, foreign nationals face language barriers and cultural differences which impede their ability to defend themselves or understand the unique U.S. criminal justice system. Consular assistance may include explaining the procedures and legal rights afforded by the U.S. system, obtaining competent legal counsel, and accessing and conveying required documentation from the home country. ${ }^{35}$ For defendants facing the death penalty, a consulate may fund expert witnesses and investigators, assist in investigations in the home country, bring mitigating witnesses to testify, and petition for clemency. ${ }^{36}$

Despite deficient enforcement throughout the United States, for over twenty years following the ratification of the VCCR the only published opinions alleging Article 36 violations involved immigration. ${ }^{37}$ In I980, for example, the Ninth Circuit held that a defendant could not be indicted for illegal reentry where he was deported without notification of his right to contact his consulate, and where he could demonstrate that lack of consular

33. S. EXEC. REP. No. 91-9, supra note 32, app. at 5 .

34. 8 C.F.R. $\S 242.2$ (g) (1997); 62 Fed. Reg. 10,312, 10,360 (Mar. 6, 1997) (INS guidelines); 28 C.F.R. $\S 50.5$ (a) (1967); 32 Fed. Reg. 1040 (Jan. 23, 1967) (FBl arrest procedures).

35. Defense lawyers and human rights organizations routinely point to substantial differences between the U.S. judicial system and those in other countries. See, e.g., Raymond Bonner, U.S. Bid to Execute Mexican Draws Fire, N.Y. Times, Oct. 30, 2000, at A20 (describing an Amnesty International researcher's example of a Mexican national arrested in Colorado who insisted that he did not need a lawyer, requesting instead to speak with the judge). Though an impractical request in the United States, it would not have been so in his own country, because in Mexico, as well as most European countries, judges routinely supervise criminal investigations. The U.S. judge in this case called the defendant's request "a clear indication that he did not understand the legal proceedings." See id.

36. See, e.g., Anne James \& Mark Warren, The Int'l Justice Project, Equal Protection: Consular assistance and Criminal Justice Procedures in the USA (AN INTRODUCTORY GUIDE FOR CONSULATES) (2002), http://www.internationaljusticeproject.org/pdfs /VCCRguide.pdf.

37. See, e.g., United States v. Rangel-Gonzales, 617 F.2d 529 (9th Cir. 1980); United States v. Calderon-Medina, 591 F.2d 529 (9th Cir. 1979). 
assistance prejudiced his deportation proceeding. ${ }^{38}$ The court noted that the INS regulation at issue was "intended to insure compliance with this country's treaty obligations to promote assistance from [an alien's] country of origin." 39

Relying on precedent from the immigration cases, criminal defendants began to challenge violations under Article 36 in the mid-1990s ${ }^{40}$ Several of these claims were raised in habeas corpus petitions of capital offenders. ${ }^{41}$ Others occurred in the context of narcotics prosecutions. ${ }^{42}$ U.S. courts generally have acknowledged the purposes and importance of the VCCR; nevertheless they have been reluctant to provide redress for Article 36 violations. In denying relief, courts have identified two concerns. First, courts have debated whether the VCCR gives rise to individually enforceable rights. Second, even where individual rights are conceded (or, more commonly, assumed without deciding), courts have questioned what remedy, if any, is appropriate for violation of these rights. This Part now examines each inquiry in turn.

\section{Individual Rights Under the VCCR?}

Though treaties were originally considered contracts between sovereigns, and thus enforceable only by government action, U.S. courts have long held that self-executing treaties may give rise to individual rights which are enforceable in the courts of a signatory nation. ${ }^{43}$ Therefore, when confronted with a VCCR violation, many U.S. courts have acknowledged that the self-executing nature of the treaty arguably gives rise to rights enforceable by individuals. ${ }^{44}$ However, other courts have refused to find that the VCCR confers a private cause of action. ${ }^{45}$ In refusing to hold that Article 36 gives rise to individual rights, the First Circuit relied heavily on

38. Rangel-Gonzales, 617 F.2d at 533 .

39. Id. at 530 .

40. Though Rangel-Gonzales was the only decision to grant relief based on the violation of the INS regulation, other decisions established that the VCCR created an individual "benefit" for which redress might be appropriate where the defendant could establish prejudice. See, e.g., CalderonMedina, 591 F.2d at 531-32.

41. E.g., LaGrand v. Lewis, 883 F. Supp. 469 (D. Ariz. 1995); LaGrand v. Lewis, 883 F. Supp. 451 (D. Ariz. 1995); Faulder v. State, 745 S.W.2d 327 (Tex. Crim. App. 1987) (en banc); Breard v. Netherland, 949 F. Supp. 1255 (E.D. Va. 1996).

42. E.g., United States v. Lombera-Camorlinga, 206 F.3d 882 (9th Cir. 2000) (en banc); United States v. Ademaj, 170 F.3d 58 (1st Cir. 1999); United States v. Salas, 168 F.3d 484 (4th Cir. 1999) (unpublished table opinion), 1998 WL 911731.

43. E.g., Head Moncy Cases, 112 U.S. 580, $598-99$ (1884) (" $[$ A] treaty may also contain provisions which confer certain rights upon the citizens or subjects of one of the nations residing in the territorial limits of the other, which partake of the nature of municipal law, and which are capable of enforcement as between private parties in the courts of the country.").

44. E.g., United States v. Chaparro-Alcantara, 37 F. Supp. 2d 1122, 1125 (C.D. 111. 1999).

45. E.g., Kasi v. Commonwealth, 508 S.E.2d 57, 64 (Va. 1998) (holding that there exists "no reported authority for thc idea that a violation of the treaty creates any legally enforceable individual rights"). 
the interpretation provided by the State Department in response to questions posed by the court. ${ }^{46}$ The court was persuaded by the State Department's view that the VCCR does not "create individual rights at all." ${ }^{\prime 47}$ However, a partial dissent vigorously criticized the court's reliance on the State Department's "self-serving" position, noting that it was "directly contrary to the Department's nonlitigation position." 48

Evidence of this nonlitigation position is plentiful. In 1973, the State Department called the requirements set forth in Article 36 of the VCCR "obligations of the highest order." 49 The Department's published instructions on consular notification and access advise law enforcement officers that a "foreign national ... has the option to decide whether to have consular representatives notified of the arrest or detention," but "[i]n all cases, the foreign national must be told of the right of consular notification and access." 50

International bodies and foreign governments have likewise concluded that the rights created by Article 36 are enforceable by individuals. ${ }^{51}$ In 1999, at the request of Mexico, the Inter-American Court of Human Rights $^{52}$ undertook a comprehensive analysis of Article 36, holding that the right to consular notification was analogous to the individually enforceable rights contained in Article 14 of the International Covenant on Civil and Political Rights. ${ }^{53}$ Additionally, scholarly opinion overwhelmingly favors individual standing for Article 36 violations. ${ }^{54}$

46. United States v. Li, 206 F.3d 56, 63 (1st Cir. 2000) (en banc) (quoting Sumitomo Shoji America, Inc. v. Avagliano, 457 U.S. 176, 184-85 (1982) (noting that the State Department's view is entitled to "great weight")).

47. Id.

48. Id. at $74 \mathrm{n} .4$ (Torruella, C.J., concurring in part, dissenting in part).

49. Luke T. Lee, Consular Law \& Practice 143 (2d ed. 1991) (quoting Dep't of State File L/M/SCA, Dep't State Digest 161 (1973)).

50. Bureau of Consular affairs, U.S. Dep't of State, Consular notification and access: Instructions for Federal, State, and Other Local Law EnForcement and Other Officials Regarding Foreign Nationals in the United States and the Rights of Consular OfFicIals to Assist THEM (n.d.) (emphasis in original), http://travel.state.gov/notification2.html.

51. See Standt v. City of New York, 153 F. Supp. 2d 417, 426 (S.D.N.Y. 2001) (noting that "in amicus briefs filed in criminal actions in the United States, other countries have recognized that the VCCR creates a private right of notification for detained individuals" and citing to amicus briefs filed on behalf of Paraguay, Argentina, Canada, Mexico, and Germany).

52. "The Inter-American Court of Human Rights is an autonomous judicial institution whose purpose is the application and interpretation of the American Convention on Human Rights." Statute of the Inter-American Court on Human Rights, art. I, O.A.S. Res. 448 (1X-0/79), available at http://wwwl .umn.edu/humanrts/oasinstr/zoas6cts.htm.

53. See Advisory Opinion OC-16/99, Inter-Am. Ct. H.R., ser. A, No. 16 (1999), http://www.corteidh.or.cr/Serie_A_ing/Serie_A_16_ing.doc.

54. See, e.g., Mark J. Kadish, Article $3 \overline{6}$ of the Vienna Convention on Consular Relations: $A$ Search for the Right to Consul, 18 Mich. J. INT'L L. 565, 565-602 (1997) (considering the text, travaux preparatoires, and practices of states to dcmonstrate that "a private 'right to consul' was intended to be conveyed by Article 36"); see also Alison Duxbury, Saving Lives in the International Court of Justice: The Use of Provisional Measures to Protect Human Rights, 31 CAL. W. INT'L L.J. 14I, 156. 59 (2000); Luna \& Sylvester, supra note 18, at 154-56; Howard S. Schiffman, Breard and Beyond: The 
Though some U.S. courts have explicitly acknowledged that Article 36 allows for foreign defendants to pursue their causes of action, ${ }^{55}$ the U.S. Supreme Court has not yet clarified this issue. In Breard v. Greene ${ }^{56}$ one of only two cases in which the Supreme Court has addressed Article 36 violations, ${ }^{57}$ the Court opined that the VCCR "arguably confers on an individual the right to consular assistance following arrest." ${ }^{358}$ However, the Court declined to decide the issue because it found Breard's claim procedurally defaulted where it was not raised in state habeas proceedings in accordance with the subsequently enacted Antiterrorism and Effective Death Penalty Act (AEDPA) ${ }^{59}$ When seized of several of the earlier VCCR cases, U.S. courts were therefore able to reject petitioner's claims without reaching the issue of remedy.$^{60}$ In cases where procedural default is not at issue, U.S. courts are still without clear guidance from the Supreme Court as to whether the VCCR grants individually enforceable rights. In the absence of an authoritative decision on the issue, most U.S. courts tend to follow the Supreme Court's lead in assuming without deciding that an individual may bring a claim under the VCCR, and then proceed to the issue of remedy. ${ }^{61}$

Status of Consular Notification and Access Under the Vienna Convention, 8 Cardozo J. INT'L \& Comp. L. 27, 37-42 (2000); Rebecca E. Woodman, International Miranda? Article 36 of the Vienna Convention on Consular Relations, 70 J. KAN. B. Ass'N 41, 41 (July 2001).

55. See, e.g., United States v. Alvarado-Torres, 45 F. Supp. 2d 986, 989 (S.D. Cal. 1999) (noting the Ninth Circuit's holding in United States v. Lombera-Camorlinga, 170 F.3d I241 (9th Cir. 1999) (establishing that where "the United States fail[s] to inform a foreign national of his rights under Article 36 , that national has standing to enforce those rights in federal court")), opinion withdrawn by $188 \mathrm{~F} .3 \mathrm{~d}$ 1177 (9th Cir. I999)).

56. 523 U.S. 37I (I998).

57. See also Federal Republic of Germany v. United States, 526 U.S. 111 (1999).

58. Breard, 523 U.S. at 376.

59. Id. Congress promulgated the AEDPA in 1996 in an effort to restrict the number and frequency of claims and appeals made under federal habeas corpus. See AEDPA, Pub. L. No. 104-132 (1996) (codified as amended in scattered sections of $8,15,18,19,21,22,28,40,42,49,50$ U.S.C., FED R. APP. P. 22, and FED. R. Clv. P. 32). Under 28 U.S.C. § 2254(e)(2), which "drastically limits the circumstances under which an evidentiary hearing will be granted when material facts were not developed in the state court," a claim not raised in state court proceedings is deemed procedurally defaulted from litigation in a federal habeas petition. Nina Rivkind \& STEven F. Shatz, CaSES AND Materials on the Death Penalty 606 (2001). Article 27 of the Vienna Convention on the Law of Treaties states that "[a] party may not invoke the provisions of its internal law as justification for its failure to perform a treaty." Vienna Convention on the Law of Treaties, opened for signature May 23, I969, art. 27, 1155 U.N.T.S. 33I, available at $\mathrm{http} / / \mathrm{www}$.un.org/law/ilc/texts/treatfra.htm. The United States has never ratified the Convention on the Law of Treaties, but the U.S. Restatement of Foreign Relations Law regards the treaty as evidence of customary international law. 2 RESTATEMENT (THIRD) OF ForEIGN ReLATIONS LaW ch. 2 (1987).

60. See Villafuerte v. Stewart, 142 F.3d 1124 (9th Cir. 1998); LaGrand v. Stewart, 133 F.3d 1253 (9th Cir. 1998); Murphy v. Netherland, 116 F.3d 97 (4th Cir. 1997).

61. E.g., United States v. Ademaj, 170 F.3d 58, 66-67 (1st Cir. 1999); United States v. Rodrigues, 68 F. Supp. 2d 178, 182-83 (E.D.N.Y. 1999). 


\section{Individual Remedy for Violations of the VCCR?}

Virtually all U.S. courts have held that in order for a defendant to obtain a remedy for a violation under Article 36, he must demonstrate that "prejudice" resulted from the lack of consular access. ${ }^{62}$ In United States $v$. Proa-Tovar, the Ninth Circuit created a three-part test to ascertain prejudice, ${ }^{63}$ and most courts have adopted the same or a similar standard. Under the test, a defendant must produce evidence that (1) he was not informed of his right to consular assistance; (2) had he known of the right, he would have availed himself of it; and (3) there is likelihood that the consulate would have been able to assist him. ${ }^{64}$ The burden is on the defendant to establish prejudiee. ${ }^{65}$

Although an early immigration case found that a defendant established a showing of prejudice and granted relief ${ }^{66}$ in most recent cases the prejudice test establishes a nearly insurmountable hurdle for defendants. For example, in United States v. Chapparo-Alcantara, the defendant demonstrated that his consulate would have advised him not to speak to police and would have assisted him in finding counsel. ${ }^{67} \mathrm{He}$ also filed affidavits illustrating that he would have exercised his right to consular assistance and followed the advice of his consul ${ }^{68}$ However, the district court held that the defendant had not shown prejudice because there was no evidence that he would have exercised his right to be silent at the moment he was notified of his right to consular access, and it was unclear when he would have been able to speak to a consular official. ${ }^{69}$ Other courts have simply avoided a finding of prejudice by conflating consular notification with Miranda warnings, holding that where a defendant was told of her Fifth Amendment right to remain silent, consular assistance would have been merely "cumulative."

Even where prejudice is established, the appropriate remedy for an Article 36 violation is unclear. In the majority of cases, defendants seek

62. See, e.g., Ademaj, 170 F.3d at 66-67; Faulder v. Johnson, 81 F.3d 515, 520 (5th Cir. 1996); United States v. Calderon-Medina, 591 F.2d 529, 531 (9th Cir. 1979); Rodrigues, 68 F. Supp. 2d at 183; United States v. Esparza-Ponce, 7 F. Supp. 2d 1084, 1097 (S.D. Cal. 1998).

63. 975 F.2d 592, 594-95 (9th Cir. 1992) (en banc).

64. Id.

65. See United States v. Alvarado-Torres, 45 F. Supp. 2d 986, $989-90$ (S.D. Cal. 1999) (quoting United States v. Lombera-Camorlinga, 170 F.3d 1241, 1244 (9th Cir. 1999), opinion withdrawn by 188 F.3d 1177 (9th Cir. 1999)).

66. See United States v. Rangel-Gonzales, 617 F.2d 529, 533 (9th Cir. 1980).

67. 37 F. Supp. 2d 1122, 1126 (C.D. 111. 1999).

68. Id.

69. Id. The Mexican consulates in many states have instituted a twenty-four-hour, toll-free line that defendants may call to receive assistance from the consulate. See Sandra L. Babcock, The Vienna Convention on Consular Relations (VCCR): Litigation Strategies, at http://www.capdefnet.org/fdprc/ contents/relevant_reading/101001-01.htm (last updated July 2001).

70. Alvarado-Torres, 45 F. Supp. 2d at 990; see also United States v. Rodrigues, 68 F. Supp. 2d 178, 184 (E.D.N.Y. 1999). 
suppression of incriminating statements, ${ }^{71}$ though some have argued for a new trial ${ }^{72}$ or commutation of a death sentence. ${ }^{73}$ However, U.S. courts have been reluctant to grant any remedy for a violation of Article $36 .^{74} \mathrm{In}$ denying the exclusionary rule granted for a Miranda violation, a distinction is often drawn between rights that are derived directly from the Constitution and those that are derived from a treaty and are thus "the substantial equivalent of a federal statute." 75

Although the rights under a treaty are not deemed "fundamental" like those derived from the Constitution, some courts have indicated that the exclusionary rule would be an appropriate remedy for treaty violations if it were included in the text of the treaty itself. ${ }^{76}$ However, the VCCR does not explicitly provide for a remedy. ${ }^{77}$ Defendants have claimed that the exclusionary rule is neverthcless mandated by customary international law. ${ }^{78}$ In Torres-Del Muro, the defondant argued that under the Restatement (Third) of Foreign Relations Law, the appropriate redress for a treaty violation is to "undo the effect of the violation" through a "restoration of the status quo ante." "Therefore, he argued, the exclusion of incriminating statements would rcstore the "status quo ante" and should bc employed for a violation of Article 36 . However, the court rejected this argument, refusing to concede that international law was applicable to the

71. E.g., Alvarado-Torres, 45 F. Supp. $2 \mathrm{~d}$ at 980.

72. E.g., Alcozer v. State, No. 05-97-00343-CR, 1999 WL 118657 (Tex. App. Mar. 9, 1999).

73. E.g., United States v. Torres-Del Muro, 58 F. Supp. 2d 931 (C.D. Ill. 1999).

74. See Rodrigues, 68 F. Supp. $2 \mathrm{~d}$ at 186 (citing the State Department for the proposition that "countries remedy breach of Article 36's notification provision through traditional diplomatic, not judicial, channels"). Cf. Torres-Del Muro, 58 F. Supp. 2d at 934 (suggesting that an action for monetary damages might be a proper remedy).

75. Ohio v. Loza, No. CA96-10-214, 1997 WL 634348, at *2 (Ohio Ct. App. Oct. 13, 1997). For a discussion of the "source-based hierarchy" argument that courts employ to deny suppression or exclusion of evidence, see Luna \& Sylvester, supra note 18, at 158 ("With treaty-based rights consigned to non-fundamental status, Vienna Convention claims are subject to the full panoply of procedural limitations ... [ [which] all but deny an effective remedy.").

76. See, e.g., United States v. Chaparro-Alcantara, 37 F. Supp. 2d 1122, 1125 (C.D. 11l. 1999) ("[l]n order for Chaparro-Alcantara and Romero-Bautista to invoke the exclusionary rule in this case, the Vienna Convention must explicitly provide for that remedy, or the violation of the treaty must rise to a level of a constitutional violation."). As a treaty is generally considered the equivalent of a federal statute, this construction follows from the maxim set out in United States v. Thompson, 936 F.2d 1249, 1251-52 (11 th Cir. 1991) (holding that a court may not suppress testimony for statutory violation unless Congress explicitly or implicitly provided exclusion as a remedy for a violation). See also United States v. Tapia-Mendoza, 41 F. Supp. 2d 1250, 1255 (D. Utah 1999), which held that

[t]he Vienna Convention does not expressly or impliedly provide for the remedy of suppression of statements of confessions where an arresting government fails to notify a foreign national of her right to contact the Consulate. This court declines to imply the existence of such remedy, and rules that the remedy of suppression is not available under the Vienna Convention.

77. See VCCR, supra note 3; see also United States v. Enger, 472 F. Supp. 490, 545 (D.N.J. 1978) ("No exclusionary rule is explicated by ... the Vienna Convention.").

78. E.g., Torres-Del Muro, 58 F. Supp. 2d at 934.

79. See 2 Restatement (Thikd) of Foreign Relations Law, supra note $59, \S 901 \mathrm{cmt}$. d. 
case, and holding that even if it were, there were less "extreme measure[s]" available through which the "[d]efendant could theoretically be placed back to "status quo ante." $\$ 80$

Until recently, ${ }^{81}$ only one state court has allowed for suppression of incriminating statements due to an Article 36 violation. ${ }^{82}$ That court recognized the "limited authority for the remedy in criminal cases involving violation of the Vienna Convention on consular notification," but nevertheless found the example of Rangel-Gonzales persuasive in suppressing the defendant's confession. ${ }^{83}$ The court also construed the Supreme Court's opinion in Breard v. Greene as suggestive that where a "violation had an effect on the trial," a remedy might be appropriate. ${ }^{84}$

\section{The Breard and LaGrand Cases in U.S. Courts}

As discussed above, litigation of Article 36 claims in U.S. courts has raised without settling issues implicating individual rights, procedural default, the effects of international treaty obligations, and remedies for violation of those obligations. The ICJ addressed each of these questions, and more, in its final decision in LaGrand. Before turning to that case, it is instructive to review the Breard and LaGrand litigation in the United States to understand the positions taken by the state and federal courts, and the eventual challenge to those positions brought in the ICJ.

\section{Breard v. Greene}

In 1992, Angel Breard, a dual citizen of Paraguay and Argentina, was arrested for rape and murder in Virginia. He was not informed of his right to consular notification and access, even though arresting officers were aware of his foreign citizenship. ${ }^{85}$ In a series of "objectively unreasonable" decisions (and against the advice of his counsel), Breard rejected an offer to plead guilty and avoid the death penalty. ${ }^{86}$ Instead, Breard opted to confess his crime in his testimony to the jury, believing it would engender their sympathy. ${ }^{87}$ Breard was convicted and sentenced to death. ${ }^{88}$ After his

80. Torres-Del Muro, 58 F. Supp. $2 \mathrm{~d}$ at 934 . The court also suggested that the "[d]efendant might theoretically be able to seek monetary damages for the violation of his notification rights through a Bivens action." Id. In Bivens v. Six Unknown Named Agents of Federal Bureau of Narcorics, 403 U.S. 388 (1971), the Supreme Court ereated a federal common law right of action against fcderal officers, who, acting under color of law, violate a constitutional right.

81. See Valdcz v. State, 46 P.3d 703 (Okla. Crim. App. 2002); infra Part lll.B.

82. State v. Reyes, 740 A.2d 7 (Del. Super. Ct. 1999).

83. Id. at 10 .

84. See id. at 12 (quoting Breard v. Greene, 523 U.S. 371, 375 (I998)).

85. See Breard v. Netherland, 949 F. Supp. I 255 (E.D. Va. I996).

86. Application of the Republic of Paraguay (Para. v. U.S.), I.C.J. (Apr. 3, 1998), at para. 9, http://www.icj-cij.org/icjwww/idocket/ipaus/ipausframe.htm.

87. See id.

88. Breard, 949 F. Supp. at 1260. 
state appeals were made and exhausted, Paraguay finally learned of Breard's incarceration. ${ }^{89}$ In 1996, Breard raised his Article 36 claim for the first time in his federal habeas petition. His petition was rejected on the ground of procedural default because the claim was not raised in his state proceedings. ${ }^{90}$ Breard then petitioned the Supreme Court for a writ of certiorari and a stay of execution. Meanwhile, Paraguay filed a federal action against state officials in Virginia for violating Breard's right to consular notification which was rejected on the basis of Eleventh Amendment state immunity. ${ }^{91}$

The Supreme Court rejected Breard's argument that the VCCR violation "trumps" procedural law. ${ }^{92}$ In a per curiam opinion, the Court held that the "later in time" rule allows for subsequently enacted federal legislation to alter or modify a treaty obligation..$^{93}$ The Court also relied on the language in Article 36(2), stating that the obligations created by Article 36 "shall be exercised in conformity with the laws and regulations of the receiving State." "94 Therefore, the Court held, because the AEDPA barred Breard's claim, it could not be heard. ${ }^{95}$

In addition to its suit against the Virginia authorities, on April 3, 1998, Paraguay filed suit against the United States in the ICJ. ${ }^{96}$ On April 9, the ICJ issued provisional measures instructing the United States to "take all measures at its disposal to ensure that Angel Breard is not executed pending the final decision in these proceedings. "97 The Supreme Court denied certiorari on Paraguay's domestic suit, indicating that it would be barred by Eleventh Amendment state immunity even were it authorized in the VCCR (which the Court determined it was not)..$^{98}$ As for the ICJ order, the Court found "nothing in our existing case law" permitted an order to

89. Application of the Republic of Paraguay, supra note 86, at para 9.

90. Breard, 949 F. Supp. at 1263 . While noting that "Virginia's persistent refusal to abide by the Vienna Convention troubles the Court," the decision went on to indicatc that regardless of the procedural default, "a violation of rights under the Convention is insufficient to permit . . relief." Id.

91. See Republic of Paraguay v, Allen, 949 F. Supp. 1269 (E.D. Va. 1996), aff'd, 134 F.3d 622 (4th Cir. 1998), cert. denied sub nom. Breard v. Greene, 523 U.S. 371, 377-78 (1998).

92. See Breard v. Greene, 523 U.S. 371, 375 (1998).

93. Id. at 376.

94. Id. at 375 (quoting VCCR, supra note 3, at art. 36(2)). The full text of Article 36(2) is as follows:

The rights referred to in paragraph 1 of this article shall be exercised in conformity with the laws and regulations of the receiving State, subject to the proviso, however, that the said laws and regulations must enable full effect to be given to the purposes for which the rights accorded under this article are intended.

VCCR, supra note 3, at art. 36(2). Although the Court quoted the "proviso" in its decision, it expressed no opinion on whether the rule of procedural default compromised the "purposes" of the notifieation requirement. See Breard, 523 U.S. at 375.

95. Breard, 523 U.S. at 376. See infra Part V.B.I for further discussion of the AEDPA.

96. See Concerning the Vienna Convention on Consular Relations (Para. v. U.S.), 1998 1.C.J. 248 (Apr. 9).

97. Id. at 257.

98. Breard, 523 U.S. at 377-78. 
the Governor of Virginia to stay the execution. ${ }^{99}$ In refusing to enforce the provisionaI measures, the Court indicated that the Executive, with its "authority over foreign relations," would be better suited to intervene if it saw fit. ${ }^{100}$ Three justices dissented from the Court's decision to deny relief, indicating that they desired more time to consider the petition more fully. ${ }^{101}$ The Supreme Court opinion was released less than one hour before Angel Breard was scheduled to be executed. The execution was carried out on time.

\section{The LaGrand Cases}

In 1982, Karl and Walter LaGrand were arrested and convicted for the murder of a bank manager during a robbery in Arizona. ${ }^{102}$ Both brothers were sentenced to death. ${ }^{103}$ Like Breard, neither man was told of his right to contact his consulate, though they were citizens of a foreign country. ${ }^{104}$ In 1998, the LaGrand brothers raised their VCCR violations for the first time in a petition for a writ of habeas corpus. ${ }^{105}$ The claims were deemed procedurally defaulted for not having been raised in earlier proceedings, and the writ was denied. ${ }^{106}$

Germany became aware of the LaGrand case in $1992 .{ }^{107}$ However, Germany did not file suit with the ICJ until February 1999, after the execution of Karl LaGrand, and with only days remaining until the scheduled execution of Walter LaGrand. ${ }^{108}$ As in Breard, the ICJ issued provisional measures ordering a stay of execution until the case was fully presented

99. Id. at 378 .

100. The Court noted that the previous evening, then-Secretary of State Madeleine Albright had, in fact, sent a letter to the Governor of Virginia "requesting that he stay Breard's execution." Id. The Secretary of State's letter expressed concern over the intemational implications of proceeding with an execution under the circumstances. In particular, it emphasized:

[t] he possible negative consequences for the many U.S. citizens who live and travel abroad.

The execution of Mr. Breard in the present circumstances could lead some countries to contend incorrectly that the United States does not take seriously its obligations under the Convention. The immediate execution of Mr. Breard in the face of the Court's April 9 action could be seen as a denial by the United States of the significance of international law.

Jefrrey Dunoff et al., International Law: Understanding Process Through Problems 47 (2001).

101. Breard, 523 U.S. at 379-81 (Stevens, J., Ginsburg, J., \& Breyer, J., dissenting). In addition to the claims raised by Breard in his petition, Justice Breyer also noted that he would like more time to consider the "potential relevance of proceedings in an international forum." Id. at 381 (Breyer, J., dissenting).

102. State v. LaGrand (Karl), 733 P.2d 1066, 1067 (Ariz. 1987); State v. LaGrand (Walter), 734. P.2d 563, 565 (Ariz. 1987).

103. LaGrand (Karl), 733 P.2d at 1067; LaGrand (Walter), 734 P.2d at 565.

104. LaGrand (Karl \& Walter) v. Stewart, 133 F.3d 1253, 1261 (9th Cir. 1998). The LaGrand brothers were citizens of Germany.

105. Id.

106. Id.

107. See Federal Republic of Germany v. United States, 526 U.S. 111,112 (1999).

108. See id. 
and decided. ${ }^{109}$ This order was given on the scheduled day of Walter LaGrand's execution. ${ }^{110}$ Germany immediately petitioned the U.S. Supreme Court to enforce the ICJ's order, but the Court refused to do so, in part because of the "tardiness of the pleas." 111 The majority opinion pointedly commented: "This action was filed within only two hours of a scheduled execution that was ordered on January 15, I999, based upon a sentence imposed by Arizona in 1984, about which the Federal Republic of Germany learned in I992." 12 What Justice Breyer illuminated in his dissent, however, was that Arizona had only admitted eight days before Walter LaGrand's seheduled execution that Arizona officials had known of the LaGrands' German citizenship at least as early as $1983 .{ }^{113}$ It was this clear admission of the Article 36 violation that prompted Germany to bring the case to the ICJ. The "tardiness" was due to further malfeasance on the part of Arizona, yet Germany (and ultimately Walter LaGrand) was penalized for it.

The ICJ Decision in LaGrand: Defining the Rights of Foreign NATIONALS

Following the executions of Karl and Walter LaGrand, Germany continued to pursue its case against the United States in the ICJ. Both governments filed pleadings and documents by March 2000, and oral hearings were held in November 2000. ${ }^{114}$ The German pleadings raised four claims: (I) that the United States violated its obligations to Germany under the VCCR, as well as its obligations to the LaGrand brothers under Article 36; (2) that the United States impermissibly prevented "full effect" to be given to the VCCR obligations in violation of Article 36(2) by employing the procedural default doctrine; (3) that the United States violated its obligation to comply with the provisional measures indicated by the ICJ by failing to take all measures at its disposal to halt the execution of Walter LaGrand; and (4) that the United States should provide to Germany a guarantee of future compliance with Article 36 in future cases against German nationals. ${ }^{115}$ For its part, the United States conceded the breach of Article

109. See Concerning the Vienna Convention on Consular Relations (F.R.G. v. U.S.), June 27, 2001 (Order of Mar. 3, 1999: Req. for the Indication of Provisional Measures), http://www.icjcij.org/icjwww/idocket/igus/igusframe.htm.

$110 . \quad$ Id.

II1. Federal Republic of Germany, 526 U.S. at 112. The Court also referred to possible jurisdictional "barriers," but did not decide, in fact, whether the Constitution prohibits an "action to prevent execution of a German citizen who is not an ambassador or consul." Id.

112. Id.

113. Id. at 113 (Breyer, J., dissenting).

114. See LaGrand, supra note 2, at para. 8.

115. Id. at para. 11 . 
36(1) of the VCCR to Germany. ${ }^{116}$ The United States went on to ask the ICJ to "declare ... that the United States has apologized to Germany for this breach, and is taking substantial measures aimed at preventing any recurrence" and to dismiss all other claims of Germany. ${ }^{117}$

With regard to each of Germany's submissions, the $1 \mathrm{CJ}$ rendered its final decision after evaluating the propriety of its jurisdiction and the arguments supporting and opposing the claim. Each submission is discussed in detail below.

\section{A. Individual Rights}

Germany's first submission asked the $1 \mathrm{CJ}$ to declare a violation of both Germany's rights under the VCCR and the rights of its citizens, Karl and Walter LaGrand. The full submission sought:

(1) [T]hat the United States, by not informing Karl and Walter LaGrand without delay following their arrest of their rights under Article 36, subparagraph 1 (b), of the Vienna Convention on Consular Relations, and by depriving Germany of the possibility of rendering consular assistance, which ultimately resulted in the execution of Karl and Walter LaGrand, violated its international legal obligations to Germany, in its own right and in its right of diplomatic protection of its nationals, under Articles 5 and 36, paragraph 1 , of the said Convention. ${ }^{118}$

The United States objected to the 1CJ's jurisdiction over the question of individual rights, alleging that it arose not through the VCCR, but rather as a question of diplomatic protection under customary international law. ${ }^{119}$ Germany, however, argued that the second sentence in Article 36(1)(a) together with 36(1)(b) conferred individual rights on the detainees, and, therefore, Germany "was injured in the person of its two nationals." $20 \mathrm{Ju}$ risdiction was appropriate, Germany maintained, because " application of the Convention'... encompasses the consequences of a violation of individual rights under the Convention, including the espousal of respective claims by the State of nationality." 21 The 1 CJ rejected the U.S. argument that the claim based on individual rights was beyond the jurisdiction of the $1 \mathrm{CJ}$, holding that, where the treaty conferred those individual

116. Id. (apologizing for a breach of Article 36 of the VCCR).

117. Id.

$118 . \quad I d$.

119. $J d$. at para. 40 (quoting the Memorial of the United States distinguishing the acknowledged breach of Germany's consular rights from the "wholly different question whether the State can espouse the claims of its national through diplomatic protection").

120. Id. at para. 38 (The second sentence of $36(1)$ (a) states: "Nationals of the sending State shall have the same freedom with respect to communication with and access to consular officers of the sending State"). VCCR, supra note 3, at art. 36(1)(a). See also id. at 181, art. 36(1)(b).

121. LaGrand, supra note 2, at para. 41. 
rights, a party to the treaty may "institute international judicial proceedings on behalf of" one of its nationals. ${ }^{122}$

The United States also argued that Germany's first submission should be deemed inadmissible because the LaGrand brothers failed to exhaust all available domestic remedics where they did not raise their VCCR claims in state courts. ${ }^{123}$ Germany countered that international law only requires the exhaustion of all remedies which are "legally and practically availablc," pointing out that the LaGrands were practically barred from raising their VCCR claims in state courts specifically because of the "failure of the United States authorities" to alert them to their rights. ${ }^{124}$ The ICJ refused to allow the United States to "rely" on the failure of the LaGrands to raise their claims in a timely manner where the United States was culpable for that situation. ${ }^{125}$

As to the merits of Germany's first submission, the United States took a firm stand on the question of whether the VCCR creates individually enforceable legal rights. The United States asserted "that rights of consular notification and access under the Vienna Convention are rights of States, and not of individuals, even though these rights may benefit individuals by permitting States to offer them consular assistance." 26 This unequivocal position is particularly interesting when juxtaposed with the confused court decisions on this issue in the United States. ${ }^{127}$ As noted above, U.S. courts frequently acknowledge that the VCCR may give rise to individual rights. However, they rarely hold this directly, instead sidestepping this issue by holding that the violation was procedurally defaulted, had no significant effect on the case's outcome, or gave rise to no remedy. ${ }^{128}$

Despite the U.S. position, the ICJ held that the plain language of Article 36 clearly provides for individual rights which could be invoked by Germany on behalf of its nationals. ${ }^{129}$ This authoritative interpretation of the status of individual rights created by the VCCR should settle a murky issue for U.S. courts. However, the ICJ did not stop there. This portion of the decision also addressed and settled another disputed issue: whether prejudice must result before a breach may be established under Article 36 . The United States contended that Germany's claim of harm arising from the Article 36 violation was merely "speculation" and "supposition[]," and

122. Id. at para. 42.

123. Id. at para. 58.

124. Id. at para. 59.

125. Id. at para. 60 .

126. Id. at para. 76 .

127. See supra notes $43-50$ and accompanying text.

128. See id. In fact, the U.S. Supreme Court took this tack in Breard, where it suggested, but did not actually hold, that the VCCR created an individual right. See Breard v. Greene, 523 U.S. 371, 376-77 (1998).

129. LaGrand, supra note 2 , at paras. $77,128(3)$. The $1 \mathrm{CJ}$ deeision was almost unanimous on this issue, with only one of the fifteen judges dissenting. 
did not constitute proof of prejudice to the LaGrands. ${ }^{130}$ Therefore, the United States argued, Germany could not prove a violation of the LaGrands' rights. Again, the ICJ disagreed with the U.S. position. The ICJ found it "immaterial" whether the LaGrands had in fact been prejudiced by the violation. ${ }^{131}$ The ICJ found it "sufficient that the Convention conferred these rights, and that Germany and the LaGrands were in effect prevented by the breach of the United States from exercising them." ${ }^{132}$ As recovery under Article 36 in U.S. courts often hinges on a finding of prejudice, ${ }^{133}$ the ICJ's dismissal of the issue as "immaterial" tacitly disfavors this preliminary inquiry.

\section{B. Procedural Default}

Germany's second submission challenged the U.S. practice of subordinating its international obligations to domestic procedural rules of law. The submission stated:

(2) [T] hat the United States, by applying rules of its domestic law, in particular the doctrine of procedural default, which barred Karl and Walter LaGrand from raising their claims under the Vienna Convention on Consular Relations, and by ultimately executing them, violated its international legal obligation to Germany under Article 36, paragraph 2, of the Vienna Convention to give full effect to the purposes for which the rights accorded under Article 36 of the said Convention are intended. ${ }^{134}$

The United States objected to the admissibility of this request, contending that Germany was asking the ICJ to "play the role of ultimate court of appeal in national criminal proceedings" and "to address and correct . . . asserted violations of U.S. law and errors of judgment by U.S. judges." ${ }^{135}$ The United States maintained that this would be an improper functioning of the ICJ. The ICJ rejected this argument, asserting that Germany's second submission merely requested that the ICJ define the permissible "scope" of Article $36 .^{136}$

In response to Germany's second submission, the ICJ observed that the U.S. procedural default rule would not undermine the purposes of the VCCR in every case. However, it held that where the rule of procedural default prevents a defendant from asserting a violation of the VCCR, it frustrates the "purposes for which the rights accorded ... are intended,"

130. Id. at para. 72.

131. Id. at para. 74. Germany vigorously asserted that the LaGrands had, in fact, been prejudiced by the lack of consular access before 1992. See id. at para. 71 .

132. Id. at para. 74.

133. See supra notes $62-70$ and accompanying text.

134. LaGrand, supra note 2, at para. 11.

135. Id. at para. 50 (omission in original).

136. Id. at para. 52 . 
and is impermissible in those cases. ${ }^{137}$ The ICJ found that the LaGrands were deprived of the ability to raise the Article 36 violation in state courts because of the violation itself, and therefore the rule of procedural default unfairly barred their claim in federal habeas corpus proceedings. ${ }^{138}$ This aspeet of the ICJ decision challenges the holdings of the U.S. Supreme Court in both Breard and LaGrand. As a result, the Supreme Court cannot allow for the rule of procedural default to vitiate the purpose of the VCCR in future cases without being in direct conflict with this ICJ decision. ${ }^{139}$

\section{Provisional Measures}

Germany's third submission to the ICJ demanded that it confront the authority and purposes of an order for provisional measures and comment on the U.S. unwillingness to enforce those measures in the LaGrand situation. The submission read:

(3) $[T]$ hat the United States, by failing to take all measures at its disposal to ensure that Walter LaGrand was not executed pending the final decision of the International Court of Justice on the matter, violated its international legal obligation to comply with the Order on Provisional Measures issued by the Court on 3 March 1999, and to refrain from any action which might interfere with the subject matter of a dispute while judicial proceedings are pending. ${ }^{140}$

Germany argued that the provisional measures were binding under Article 41 of the ICJ charter. ${ }^{141}$ It went on to allege that the United States "committed a threefold violation" of those measures. ${ }^{142}$ First, the Supreme Court refused to grant a stay of execution based on the provisional measures. ${ }^{143}$ Second, the U.S. Solicitor General, "in full knowledge of the Order of the International Court," argued that provisional measures of the ICJ were not binding and furnished no basis for judicial relief. ${ }^{144}$ Germany maintained that this statement from "a high-ranking official of the Federal Government ... had a direct influence on the decision of the Supreme Court." 145 According to Germany, the third violation occurred when the

137. Id. at para. 91 .

138. Id. at paras. 90-91.

139. Of course, this observation applies equally to all domestic U.S. courts.

140. Id. at para. 92.

141. Id. at para. 93.

142. Id. at para. 94 .

143. Id.

144. Id.

145. Id. (omission in original). 
Governor of Arizona ignored the ICJ's order and refused to grant a stay of execution. $^{146}$

The United States argued that it fully complied with the measures by immediately transmitting the order to the Governor of Arizona, "the one official who, at that stage, might have had legal authority to stop the exeeution." 147 The United States also intimated that the nature of the federalized American system prevented the United States from taking any further action. ${ }^{148}$ Finally, the United States opined that the "weight of publicist's commentary" did not believe ICJ provisional measures to be more than "advisory" and urged the Court not to consider that "difficult and controversial legal question." 149

In light of this strong difference of opinion, perhaps it is not surprising that the ICJ tackled the previously undecided question head on, observing that "the dispute which exists between the Parties with regard to this point essentially concerns the interpretation of Article $4 \mathrm{I}$, which ... has been the subject of extensive controversy in the literature."150 The ICJ was not exaggerating when it deemed the range of controversy on this issue "extensive." 151 Perhaps most significantly, the U.N. Security Council, a body charged with the power to enforce ICJ orders, ${ }^{152}$ has questioned its own ability to enforce an indication of provisional measures. ${ }^{153}$ Nevertheless, after taking into consideration the "text and purpose" of Article 41, the ICJ held that:

the power to indicate provisional measures entails that such measures should be binding, inasmuch as the power in question is based on the necessity, when the circumstances call for it, to safeguard, and to avoid prejudice to, the rights of the parties as determined by the final judgment of the Court. ${ }^{154}$

146. Id. Germany also pointed out that the Governor of Arizona refused the stay even where "the Arizona Executive Board of Clemency - for the first time in the history of this institution-had issued a recommendation" for the stay, based in part on the international implications of the case. $I d$.

147. Id. at para. 95.

148. Id.

149. Id. at para. 96. But see Louis Henkin, Breard: Provisional Measures, U.S. Treaty Obligations, and the States, 2 AM. J. INT'L L. 679, 680 (1998) (arguing that provisional measures of the ICJ are lcgally binding, because the obligation derives from Article $41(1)$ of the Statute of the ICJ, and "[u]nder international law, and under the U.S. Constitution, the Court's Order had the same character and status as a U.S. treaty obligation as does the Statute of the Court underlying the Order").

150. LaGrand, supra note 2, at para. 99.

151. See Charles B. Radlauer, A Clash of Power and Jurisdiction: The United States Supreme Court v. The International Court of Justice, 11 ST. Thomas L. REv. 489, 505-08 (1999) for an extensive discussion of the debate.

152. See U.N. ChARTER art. 94, para. 2.

153. See 2 Restatement (ThiRD) of Foreign Relations LaW, supra note 59, \& 903 n.6 at $369-$ 70 (noting that the Security Council has questioned its own authority to enforce non-final orders).

154. LaGrand, supra note 2, at para. 102. 
The ICJ went on to list the various U.S. agents and authorities that failed to "take all the steps they could have taken"155 to comply with the ICJ orders. ${ }^{156}$ This list includes the State Department, the Solicitor General, the Governor of Arizona, and the U.S. Supreme Court. ${ }^{157}$ Finally, the ICJ conceded that the United States was under great time pressure and that the question of whether such orders were binding was an open and unsettled one. ${ }^{158}$ The implicit warning is that these excuses will not be adequate in the future.

\section{Future Compliance}

Germany's final submission to the ICJ was somewhat unusual in that it asked for a guarantee of future compliance, as opposed to a declaration of a past violation:

(4) [T]hat the United States shall provide Germany an assurance that it will not repeat its unlawful acts and that, in any future cases of detention of or criminal proceedings against German nationals, the United States will ensure in law and practice the effective exercise of the rights under Article 36 of the Vienna Convention on Consular Relations. In particular in cases involving the death penalty, this requires the United States to provide effective review of and remedies for criminal convictions impaired by a violation of the rights under Article 36. ${ }^{159}$

The United States maintained throughout the proceedings that it was "keenly" aware of the importance of the obligations of consular access and was "working intensively to improve understanding of and compliance with consular notification and access requirements throughout the United States, so as to guard against future violations of these requirements." 160 Taking into account the specific measures that the United States was undertaking to improve compliance, ${ }^{161}$ the ICJ found that the United States had met Germany's "general demand for an assurance of non-repetition." 162

155. Id. at para. 115 .

156. See id. at paras. 111-16.

157. See id. Conspicuously absent from this list is the President of the United States, who is responsible for making sure the "Laws" of the United States are "faithfully executed." See U.S. ConST. art. II, $\& 3$.

158. See LaGrand, supra note 2, at para. 116.

159. Id. at para. 117.

160. Id. at para. 121 .

161. In its Memorial, the United States elaborated on the programs it was implementing to ensure compliance with Article 36:

[t]his effort has included the January 1998 publication of a booklet entitled 'Consular

Notification and Access: Instructions for Federal, State and Local Law Enforcement and

Other Officials Regarding Foreign Nationals in the United States and the Rights of Consular

Officials to Assist Them,' and development of a small reference card designed to be carried by individual arresting officers.

Id. (alteration in original).

162. Id. 
However, Germany sought more than a general assurance. In its Memorial, Germany alluded to other "German nationals detained after January I, 1998, who claim not to have been informed of their consular rights," and stressed that violations of consular rights which result in "death sentences and executions cannot be remedied by apologies or the distribution of leaflets." "163 Instead, Germany insisted that these violations will only be remedied by "changes in U.S. law and practice."164 The ICJ concurred that "an apology is not sufficient" to remedy an Article 36 violation which results in "prolonged detention" or "severe penalties." 165 Though it did not find that any existing U.S. law was "inherently inconsistent with the obligations undertaken by the United States in the [VCCR]," it indicatcd that, where serious conscquences are at stake for a defendant, "it would be incumbent upon the United States to allow the review and reconsideration of the conviction and scntence by taking account of the violation[s]" of his rights. ${ }^{166}$ The ICJ left the manner of this review to the discretion and implementation of the United States. ${ }^{167}$

Although Germany's first three submissions clarify important legal questions with regard to the VCCR and ICJ authority, it is the fourth submission that reveals the nature of the rift between U.S. jurisprudence and the international community at large. Germany's "particular" emphasis on death penalty cases brings into sharp focus the growing international disapproval of the use of this ultimate punishment in the U.S., especially when it is employed against non-U.S. citizens. ${ }^{168}$ The ICJ decision obligates the United States to provide the means by which such cases can be reviewed and reconsidered when the death penalty is at stake. ${ }^{169}$ The next Part discusses the small effect this mandate has had on subsequent VCCR litigation in U.S. courts.

163. Id. at para. 122.

164. Id.

165. Id. at para. 123.

166. Id. at para. 125.

167. See id.

168. At least seventy-six countries have abolished the death penalty. See Amnesty Int'l, Website Against the Death Penalty, at http://web.amnesty,org/rmp/dplibrary.nsf/index?openview (last visited Aug. 4, 2003).

Since the reinstatement of the death penalty in 1977 , more than 120 foreign nationals (from over 40 countries) have been sentenced to death in the United States. See AMNESTY INT'L, UNITED STATES of America: A Time for action-Protecting the Consular Rights of foreign Nationals Facing the DeATh Penalty, Aug. 2001, at 4, http://web.amnesty.org/aidoc/aidoc_pdf.nsf/Index/ AMR511062001ENGLISH/\$File/AMR51 10601.pdf [hereinafter TIME FOR ACTION].

169. See LaGrand, supra note 2, at para. 125. 
III

\section{IMPACT OF THE ICJ'S LAGRAND DECISION ON U.S. COURTS}

\section{A. Disappointing Judicial Response in the United States After LaGrand}

The ICJ's LaGrand decision was released June 27, 2001. Since then, most state and federal courts faced with Article 36 claims have neither mentioned the ICJ decision nor departed from recent domestic precedent denying relief. For example, several recent decisions in U.S. courts have bypassed the "individual rights" question, while holding that the VCCR does not provide the remedy sought by the defendant. ${ }^{170}$ Other courts have held that the VCCR does create individually enforceable rights, but that defendants failed to show that they were "prejudiced" by the violation of those rights. ${ }^{171}$ Still others have held that the VCCR does not give individuals a private cause of action at all. ${ }^{172}$

Though most courts do not mention the ICJ's interpretation of the VCCR in LaGrand, defense attorneys have begun to employ that decision to bolster their VCCR claims. As a result, several state and federal courts recently have examined the ICJ's decision in the course of deciding these claims. ${ }^{173}$ However, only one district court has found that LaGrand mandates rights for defendants.

In U.S. ex rel. Madej v. Schomig, a state prisoner's petition for habeas corpus alleged that after LaGrand, U.S. states are foreclosed from finding a VCCR claim procedurally defaulted. ${ }^{174}$ The district court agreed with petitioner, holding that pursuant to the ICJ decision in LaGrand, a state could no longer strictly rely on a procedural rule as a basis for denial of relief of defendant's VCCR claims. ${ }^{175}$ The district court also held that when the United States signed the Optional Protocol, it "voluntarily submitted to the jurisdiction of the I.C.J. to resolve disputes over the interpretation of the Vienna Convention." 176 Therefore, the court went on, the ICJ finding that the VCCR creates "individually enforceable rights" resolved "the question

170. E.g., United States v. Contreras-Cortez, No. 01-8030, 2002 WL 734772 (10th Cir. Apr. 26, 2002); United States v. Minjares-Alvarez, 264 F.3d 980 (10th Cir. 2001); State v. 1ssa, 752 N.E.2d 904 (Ohio 2001); State v. Tuck, 766 N.E.2d 1065 (Ohio Ct. App. 2001).

171. E.g., United States v. Cazares, No. 01-2180, 2003 WL 894064 (10th Cir. Mar. 7, 2003); United States v. Duarte-Acero, 296 F.3d 1277 (1 Ith Cir. 2002); State v. Lopez, 633 N.W.2d 774 (Iowa 2001 ).

172. E.g., United States v. Emuegbunam, 268 F.3d 377 (6th Cir. 2001); United States v. De La Pava, 268 F.3d 157 (2d Cir. 2001); State v. Martinez-Rodriguez, 33 P.3d 267 (N.M. 2001); Bell v. Commonwealth, 563 S.E.2d 695 (Va. 2002).

173. See, e.g., Minjares-Alvarez, 264 F.3d at 987 n.3; United States ex rel. Madej v. Schomig, 223 F. Supp. 2d 968 (N.D. III. 2002); Valdez v. State, 46 P.3d 703 (OkIa. Crim. App. 2002); Bell, 563 S.E.2d at 705-07; State v. Navarro, 659 N.W.2d 487 (Wis. Ct. App. 2003).

174. 223 F. Supp. $2 d$ at 978.

175. Id. at $978-79$.

176. Id. at 979 (citing VCCR Optional Protocol, supra note 13). 
most American courts . . have left open." 177 However, despite finding that the ICJ conclusively resolved the questions of individual rights and procedural bars, the court still found that a finding of prejudice was necessary to grant relief for the VCCR violation. ${ }^{178}$ Where it found the evidence of petitioner's guilt "substantial," the court refused to overturn the conviction. ${ }^{179}$ And though the court acknowledged that participation of a consulate could be "significant" during the sentencing phase, the court declined to consider the prejudice to petitioner at his sentencing, since it had already granted relief from his death sentence on other grounds. ${ }^{180}$ On the government's motion to reconsider, the district court reiterated its view that the ICJ's interpretation of the VCCR was authoritative:

[T] he interpretations of the Vienna Convention by the International Court of Justice (I.C.J.) are binding as to the terms of the treaty. To disregard one of the I.C.J.'s most significant decisions interpreting the Vienna Convention would be a decidedly imprudent course. [A]fter LaGrand. . . no court can crcdibly hold that the Vienna Convention does not create individually enforceable rights. ${ }^{181}$

Despite the categorical language used by this court, the majority of courts that have acknowledged the ICJ's decision in LaGrand have been reluctant to afford it much weight or influence. ${ }^{182}$

In one such case, State v. Navarro, the Wisconsin Court of Appeals considered a claim under the VCCR as an issue of first impression in Wisconsin. ${ }^{183}$ The court held that the defendant had no standing because the VCCR "does not create a private right that a foreign national can enforce in a state criminal proceeding." 184 To reach this conclusion, the court relied on "customary practices" of other U.S. jurisdictions and the position of the State Department. ${ }^{185}$ However, because the defendant presented an expert who testified that the LaGrand decision required a different outcome, the court specifically addressed the ICJ's decision. ${ }^{186}$ The court read the ICJ's conclusion that the VCCR "creates individual rights, which ... may be invoked in [the ICJ] by the national State of the detained

177. Id.

178. Id.

179. Id. at 980 .

180. Id.

181. United States ex rel. Madej v. Schoming, No. 98 C 1866, 2002 WL 31386480, at *1 (N.D. 111. Oct. 22, 2002) (denying reconsideration of motion).

182. See, e.g., Commonwealth v. Diemer, 785 N.E.2d 1237, 1242 n.8 (Mass. App. Ct. 2003) ("Most courts which have addressed the issue post LaGrand have given the decision little deference."); see also United States v. Ortiz, 315 F.3d 873, 887 (8th Cir. 2002) (holding that even if individual rights are created by VCCR, no remedy is appropriate).

183. 659 N.W.2d 487, 488 (Wis. Ct. App. 2003)

184. Id.

185. Id. at 492 .

186. Navarro's expert was Douglass Cassel, Clinical Associate Professor of Law and Director, Center for International Human Rights, Northwestern University School of Law. 
person," 187 to imply that an individual could not assert those rights in domestic courts on his own behalf. ${ }^{188}$ Though this narrow reading ignores the obvious fact that the ICJ used permissive, not exclusive, language ("may be invoked") and had little reason in that context to affirm that Walter and Karl LaGrand could avenge their individual rights in U.S. courts (as Walter and Karl LaGrand had both been dead for over two years at the time of the LaGrand decision), other U.S. courts have also chosen to limit the reach of LaGrand in precisely the same manner. ${ }^{189}$

\section{B. A Glimmer of Hope: The Valdez Case}

The outcome of the LaGrand case has not gone entirely unnoticed in U.S. courts. A recent capital case in Oklahoma has attracted a significant amount of attention because it marks the first time since the LaGrand decision that a stay of execution was granted, at least in part, based on the ICJ's interpretation of Article $36 .{ }^{190}$ In 1990, Gerardo Valdez, a citizen of Mexico, was convicted in Oklahoma for the 1989 murder of Juan Barron. ${ }^{191}$ At the time of his arrest, Valdez was not informed of his VCCR right to contact the Mexican consulate for assistance, and he signed a waiver of his Miranda rights before confessing to the crime. ${ }^{192}$ In his defense, Valdez claimed temporary insanity, but his court-appointed attorney failed to investigate Valdez's medical history or conduct a routine background check into his childhood. ${ }^{193}$ Valdez was sentenced to death. ${ }^{194}$

In April 2001, after more than ten years on death row and less than two months before his scheduled exeeution, Mexico learned of Valdez's case and filed a petition for clemency with the Oklahoma Pardon and Parole Board. ${ }^{195}$ The Board, for only the second time in thirty-five years, recommended that the death sentence be commuted to life in prison without parole after Mexico uncovered significant evidence of multiple head injuries suffered by Valdez in childhood, including a life-threatening head trauma that caused brain damage when he was a teenager. ${ }^{196}$ On June 16, after receiving a phone call from President Vicente Fox of Mexico, the Governor of Oklahoma announced a thirty-day reprieve in which to consider the issue of clemency. ${ }^{197}$ Governor Keating indicated that he was

187. LaGrand, supra note 2, at para. 77.

188. Navarro, 659 N.W.2d at 493.

189. See, e.g., Bell v. Commonwealth, 563 S.E.2d 695, 706 (2002).

190. See Greiner, supra note 19.

191. TIME FOR ACTION, supra note 168 , at 8.

192. There is evidence that Valdez, whose English was not good, misunderstood the import of the waiver. See id. at 9.

193. Id. at 8-9.

194. Id. at 9.

195. Id.

196. Id.

197. See Greiner, supra note 19. 
discussing the VCCR violations (which he deemed "regrettable and inexcusable"198) with the State Department. According to the Governor, the State Department concurred with him that the violation "should not be the sole determining factor." 199

On July 20, Governor Keating denied clemency for Valdez. In a letter to President Fox, he wrote:

As promised during our telephone conversation, I granted a thirty day stay of execution to allow for appropriate review and reconsideration of the conviction and sentence in this case. In the interim, the International Court of Justice handed down its decision in the LaGrand Case (Germany v. United States of America). You should know that my staff and I have consulted throughout this process with the United States Department of State and the United States Department of Justice about the legal aspects of the consular notification issue. Taking the decision in [LaGrand] into account, I have conducted this review and reconsideration of Mr. Valdez's conviction and sentence by taking account of the admitted violation of Article 36 of the Vienna Convention regarding consular notification, as well as the information provided by, among others, representatives of your government. ${ }^{200}$

The twice repeated reference to "review and reconsideration" is language taken directly out of the LaGrand decision. ${ }^{201}$ Despite the fact that LaGrand determined the question of prejudice to be irrelevant, the Governor called the acknowledged violation of Article 36 "harmless error." ${ }^{202}$ Yet, several recent decisions indicate that the evidence provided by the Mexican consulate could well have had a significant impact on the outcome of Valdez's case. In Hall v. Washington, the Seventh Circuit held that " $[w]$ here it is apparent from evidence concerning the crime itself, from conversation with the defendant, or from other readily available sources of information, that the defendant has some mental or other condition that would likely qualify as a mitigating factor, the failure to investigate will be ineffective assistance." ${ }^{203}$ Additionally, the Sixth Circuit recently opined that, "while juries tend to distrust claims of insanity, they are more likely to

198. TIME FOR ACTION, supra note 168 , at 9.

199. Id.

200. Id.

201. See LaGrand, supra note 2, at para. 125.

202. See TIME FOR Action, supra note 168 , at 9.

203. 106 F.3d 742, 749-50 (7th Cir. 1997), cert. denied, 522 U.S. 907 (1997). In at least eighty cases, appellate courts have reversed death sentences on the grounds that the failure to develop and produce mitigating evidence such as brain damage constitutes ineffective assistanee of counsel. See The INT'L Justice Project, MENTAL ILLNess at http://www.internationaljusticeproject.org/ illness.cfm; The INT'L Justice Project, Mental Retardation at http://www.internationaljusticeproject.org/retardation.cfm. 
react sympathetically when their attention is drawn to organic brain problems." 204

Valdez's new execution date was set for August 30, 2001. ${ }^{205}$ However, on August 17, Governor Keating granted a second thirty-day reprieve, citing the "complicated questions of international law which have been presented by this case." ${ }^{206}$ The second reprieve was intended to allow the government of Mexieo and the attorneys for Valdez time to review their legal options. ${ }^{207} \mathrm{~A}$ spokesperson stressed that the stay was "absolutely no indication that Governor Keating [was] reconsidering his earlier decision" to deny clemency. ${ }^{208}$ On August 22, Valdez's attorneys filed a petition with the Oklahoma Court of Criminal Appeals, arguing that the June 27 binding judgment of the ICJ in LaGrand should be applied by the U.S. courts. ${ }^{209}$ On September 10,2001, the court granted an indefinite stay of execution to Gerardo Valdez. In granting its order, the court referred to the "unique and serious matter involving novel legal issues and international law" that was presented in the appeal. ${ }^{210}$

In May 2002, the Oklahoma Criminal Court of Appeals granted relief for Valdez. However, it avoided using the VCCR violation as the legal basis. ${ }^{211}$ Instead, the court held that the failure of Valdez's counsel to uncover the mitigating evidence that the Mexican consulate later provided was ineffective assistance of counsel, which mandated resentencing. ${ }^{212}$ The court observed that LaGrand arguably created "new law" with regard to individual rights and the use of procedural default. ${ }^{213}$ Nevertheless, the court held Valdez's VCCR claims were untimely, pursuant to the Supreme Court's determination in Breard that the procedural default doctrine applies to VCCR violations. ${ }^{214}$ Though reeognizing the inconsistent authority, the court observed, "until such time as the supreme arbiter of the law of the United States changes its ruling, its decision in Breard controls this issue."215 $^{215}$

204. Glenn v. Tate, 71 F.3d 1204, 1211 (6th Cir. 1995) (citing Brewer v. Aiken, 935 F.2d 850, 861-62 (7th Cir. 1991) (Easterbrook, J., concurring)).

205. TIME FOR ACTION, supra note 168, at 10.

206. Valdez v. State, 46 P.3d 703, 704 (Okla. Crim. App. 2002).

207. Governor Approves Execution Reprieve for Diplomatic Appeal, Shawnee Online, at http://www.news-star.com/stories/081801/gov_keatting.shtml.

208. Id.

209. See Brooke A. Masters, U.S. Deprived Mexican of Fair Trial, Appeal Says, WASH. Post, Aug. 23, 2001, at A08 ("Valdez's attorneys are relying heavily on a June decision from the International Court of Justicc, which they say changed the rules for [VCCR] cases.").

210. See Ron Jenkins, Oklahoma Appeals Court Grants Stay, Assoc. Press, Sept. 10, 2001.

211. See Valdez, 46 P.3d 703.

212. Id. at 710-11.

213. Id. at 709.

214. See supra Part 1.C.1.

215. Valdez, 46 P.3d at 709. 
IV

The Aftermath of LaGrand: Mexico's Challenge to the UNITED STATES

\section{A. Mexico Turns to the ICJ}

Though Gerardo Valdez no longer faced the death penalty, resolution of his case only widened the chasm between the state of domestic law, as determined by U.S. courts, and international law, as determined by the ICJ's decision in LaGrand. This gulf is of concern to many nations, but perhaps to none as much as Mexico. Of approximately 112 foreign nationals under death sentence in the United States, fifty-four are Mexican. ${ }^{216}$ The United States has executed five Mexican nationals since 1976, each after being denied his right to consular assistance under the VCCR. ${ }^{217}$

In August 2002, the Mexican Congress passed a joint resolution asking Texas Governor Rick Perry and President George W. Bush to halt the execution of Javier Suarez Medina in Texas. ${ }^{218}$ In addition, sixteen foreign countries filed amicus briefs and requests for clemency. Despite this activity and clear VCCR violations, Texas executed Suarez on August 14. ${ }^{219}$ After the execution, Mexican President Vicente Fox cancelled a scheduled meeting with George W. Bush in protest. ${ }^{220}$

When Governor Keating pronounced the VCCR violations in Gerardo Valdez's case "harmless" and denied executive clemency, Mexico called the Oklahoma Governor's action "contrary to international law"221 and publicly vowed that it would "take all available legal actions in the United States, as well as international tribunals ... in order to preserve the life of our fellow citizen and obtain clemency."222 Then, on January 9, 2003, only months after the clemency process failed to provide a reprieve for Suarez in Texas, Mexico sued the United States in the ICJ, citing the "irreconcilable views regarding the interpretation and application of Article 36 " held by the United States and Mexico. ${ }^{223}$ The application invoked the jurisdiction of the ICJ under the Optional Protocol Concerning the

216. See Death Penalty Information Center at http://www.deathpenaltyinfo.org/ article.php?did=198\&scid=31\#Reported-DROW (last updated Aug. 6, 2003).

217. Id.

218. Karen Brooks, Fox Asks Perry to Suspend Execution, Dallas-Ft. Worth Star-Telegram, Aug. 13, 2002, http://www.dfw.com/mld/dfw/3853008.htm.

219. Ginger Thompson, An Execution in Texas Strains Ties with Mexico and Others, N.Y. Times, Aug. 15, 2002, at A6.

220. Id.

221. Raymond Bonner, Mexican Killer Is Refused Clemency by Oklahoma, N.Y. Times, July 21, 2001 , at $\mathbf{A} 8$.

222. Mexico Pledges to Appeal Planned U.S. Execution in International Tribunals, Assoc. Press, July $21,2001$.

223. Concerning the Vienna Convention on Consular Relations (Mex. v. U.S.), Jan. 9, 2003 (Application Instituting Proceedings Submitted by the Government of the United Mexican States) at para. 5 [hereinafter Application]. 
Compulsory Settlement of Disputes, and sought to "establish definitively its rights and those of its nationals under Article 36."224

\section{Mexico's Case Against the United States}

The written application detailed the failure of U.S. state and federal courts to provide relief pursuant to the mandates of the LaGrand case in actions brought by Mexican nationals whose rights under the VCCR had been violated. ${ }^{225}$ The application also summarized the failure of diplomatic overtures made by Mexican and international officials to U.S. officials, with specific reference to the cases of Valdez and Suarez. Mexico submitted that fifty-four of its nationals were currently on death row in the United States and briefly addressed the circumstances of each prisoner, including the lack of consular notification or judicial remedy in each case. ${ }^{226}$

The remedies sought by the Mexican application included a declaration of the international legal obligations of the United States, including obligations "not to apply the doctrine of procedural default," "to establish a meaningful remedy at law" for VCCR violations, and to restore the status quo ante for Mexican nationals convicted and sentenced after violations of the VCCR. ${ }^{227}$ Mexico also asked the ICJ to require the United States to give Mexico a full guarantee of "non-repetition of the illegal acts." 228

To protect its interests pending the final decision, Mexico further requested that the ICJ issue an order of provisional measures instructing the U.S. government to take "all measures necessary to ensure that no Mexican national be executed" and to ensure that "no action is taken that might prejudice the rights of the United Mexican States or its nationals with respect to any decision this Court may render on the merits of the case."229 In response, the ICJ set a date, January 21,2003 , for oral arguments concerning this request for the indication of provisional measures.

Though the LaGrand decision was issued in June 2001, the U.S. government never formally stated its official position with regard to the judgment. Therefore, the oral arguments in the Mexican case provided the first opportunity for the world to hear the U.S. position on the VCCR in light of LaGrand.

\section{The Positions of the United States and Mexico Post-LaGrand}

At oral argument, the parties put forward their views on whether provisional measures were necessary pending the ICJ's final decision on the

224. Id.

225. Id. at paras. 28-42.

226. $J d$. at paras. 67-267.

227. Id. at para. 281.

228. Id.

229. Concerning Avena and othcr Mexican Nationals (Mex. v. U.S.), 2003 WL 256903 (1.C.J. Jan. 21, 2003). 
merits of the case. Noting that a decision would not be likely before 2005, Mexico pointed out that at least three of its nationals had exhausted all judicial channels available to them in the United States, and could have their execution dates set within a matter of months. ${ }^{230}$ "Absent an order of provisional measures," Mexico argued, "Mexican nationals will be executed while this case is pending."231 The Mexican representatives also emphasized that Mexico was not seeking release or retrial of any person "at this time," but rather, was requesting the "narrowest conceivable relief consistent with its objective to prevent irreparable injury."232 Mexico maintained that LaGrand "resolved every issue that might be relevant to the request for provisional measures" 233 and therefore "compels the issuance of the order sought." 234

At its first opportunity to respond, the United States declared its "strong opposition" to Mexico's request and maintained that provisional measures were unnecessary either "for the preservation of rights" or "because of the urgency of events." 235 William H. Taft IV, the Legal Adviser to the U.S. Department of State, explained the U.S. position. When a foreign national's VCCR rights are violated and a severe penalty imposed, he conceded, the LaGrand decision requires the United States to provide for review and reconsideration of the conviction and sentence. Yet, he emphasized that the LaGrand decision left the means for implementing this remedy up to the United States. Taft further informed the ICJ that the United States was in full compliance with LaGrand because the clemency process already provided the required review and reconsideration. According to Taft, this form of review and reconsideration had "proved effective in every case so far" and this assurance should be "sufficient" to enable the Court "to dispose of requests for provisional measures."236

To support the contention that executive clemency provides review and reconsideration adequate to meet the directive of LaGrand, the United States pointed out that three of the fifty-four Mexican nationals on death row had their sentences commuted by the Governor of Illinois. ${ }^{237}$ The

230. Concerning Avena and other Mexican Nationals (Mex. v. U.S.), Jan. 21, 2003 (Oral Arguments at 9:30 a.m.) at para. 55, available at $\mathrm{http}: / \mathrm{www} . \mathrm{icj}$-cij.org/icjwww/idocket/imus/imuscr/ imus_icr2003-01_20030121.PDF [hereinafter Oral Arguments 1].

231. Id. at para. 52.

232. Id. at paras. 106-07.

233. Id. at para. 49.

234. Id. at para. 117.

235. Concerning Avena and other Mexican Nationals (Mex. v. U.S.), Jan. 21, 2003 (Oral Arguments at 11:30 a.m.) at para. 1.2, available at http://www.icj-cij.org/icjwww/idocket/imus/ imuscr/imus_icr2003-02_20030121.PDF [hereinafter Oral Arguments II].

236. Id. at para. 1.10 .

237. On January 11, 2003, lllinois Governor George Ryan commuted the sentences of 167 condemned inmates, clearing lllinois' death row in "a move unprecedented in scale in U.S. history." CBS News, Ryan Clearing Illinois Death Row, Jan. 11, 2003, at http://www.cbsnews.com/stories/ $2002 / 12 / 30 /$ national/main534639.shtml. Three of the reprieved prisoners wcre Mexican nationals, all of 
United States also discussed in detail the cases of Valdez and Suarez to illustrate thc process by which the United States has undertaken to provide review and reconsideration.

In the case of Gerardo Valdez, the United States provided the ICJ with the copies of the letters the State Department wrote to Governor Keating, asking him to "take the failure of consular notification into account when considering Mr. Valdez's clemency petition. ${ }^{.238}$ Keating clearly expressed that he took account of the admitted violation and conducted a "review and reconsideration" in keeping with LaGrand, though he ultimately concluded that "any possible prejudice to Mr. Valdez was small and was outweighed by other factors."239

Turning to Suarez, the United States observed that a Board of Pardons conducts the clemency process in Texas. In this case the State Department Legal Adviser also wrote a "detailed letter" to the Board Chairman, confirming the violation of Article 36 and requesting review and reconsideration in light of that violation. ${ }^{240}$ The Board refused to commute Suarez's sentence, and the Board Chairman reported this conclusion to the Legal Adviser. ${ }^{241}$ The United States argued that the obligation imposed by LaGrand was not "an obligation of result," but rather only "envision[ed] a change in outcome if the decision maker concludes that a change is warranted."242 Therefore, the argument went, since both cases had been reviewed by a decision maker, the U.S. procedures constituted review and reconsideration in accordance with LaGrand.

Mexico viewed the obligation of LaGrand differently, and in its response to the United States it commented on the clemency process in which the United States was placing such confidence. To begin, Mexico emphasized that the definition of review and reconsideration was "the heart of one of the disputes between Mexico and the United States in these proceedings." 243 It averred that the "standardless, secretive and unreviewable process that is called clemency cannot and does not satisfy" the mandate of LaGrand. ${ }^{244}$ Highlighting Suarez, Mexico described why it deemed clemency an inadequate forum for this review.

Mexico quoted at length from the letter that the Legal Adviser sent to the Chairman of the Texas Board of Pardons, asking them to carefully

whom were named in Mexico's January 9 application before the ICJ. See Application, supra note 223, at paras. 227-38.

238. Oral Arguments Il, supra note 235, at para. 3.12.

239. Id. at para. 3.14.

240. Id. at para. 3.19. A copy of this letter was also filed with the ICJ.

241. Id. at para. 3.21 .

242. Id. at para. 3.22 .

243. Concerning Avena and othcr Mexican Nationals (Mex. v. U.S.), Jan. 21, 2003 (Oral Arguments at 3:00 p.m.) at 12 , available at http://www.icj-cij.org/icjwww/idocket/imus/imuscr/ imus_icr2003-03_20030121.PDF [hereinafter Oral Arguments 111].

244. Id. 
consider the VCCR violation in Suarez. Mexico focused on the fact that the Legal Adviser asked that "regardless of the outcome, the Board consider preparing a written statement setting out the Board's consideration of this issue" because that statement might prove helpful "in any subsequent legal proceedings."245 According to Mexico, the letter "clearly conveys" that the decision to grant or deny clemency was "wholly within the unfettered discretion" of the Texas Board of Pardons. ${ }^{246}$ Mexieo also observed that, contrary to the Legal Adviser's request, the Texas Board of Pardons did not explain the denial of clemency. ${ }^{247}$ Following its usual practice, the Board did not meet to discuss the VCCR violation, the request for a hearing, or any other aspect of the clemency petition. ${ }^{248}$ Instead, each member of the Board "voted-by fax - to deny commutation." 249 Finally, Mexico pointed out that in three decades the Board has only commuted one death sentence. ${ }^{250}$ At the time of oral arguments, Texas had executed over 288 men and women since 1976. ${ }^{251}$

Nevertheless, the United States maintained that clemency, an "integral mechanism in the administration" of criminal law and the "fail-safe" in the U.S. criminal justice system, allowed for the review and reconsideration required by LaGrand. ${ }^{252}$ The United States went on to remind the ICJ that it was "not to specify domestic law legal mechanisms" and had therefore left to the United States the "choice of means" to meet its obligations. ${ }^{253}$ However, as the United States conceded, it is the province of the ICJ to "describe the requirements of international law" and therefore to say when a country has not met those requirements. ${ }^{254}$

\section{The ICJ Orders Provisional Measures}

On February 5, 2003, the ICJ issued a provisional order that the United States "take all measures necessary" to ensure that three Mexiean nationals are not executed pending a final decision in the case. ${ }^{255}$ Though Mexico asked for a more sweeping order to prohibit the United States from

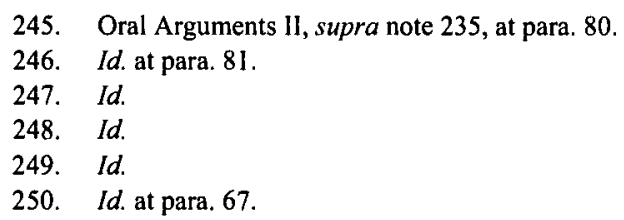

251. See CBS News, Texas Executes 300th Prisoner, Mar. 20, 2003, at http://www.cbsnews.com/ stories/2003/03/2S/national/main545890.shtml.

252. Concerning Avena and other Mexican Nationals (Mex. v. U.S.), Jan. 21, 2003 (Oral Arguments at $6: 00$ p.m.) at 20 , available at http://www.icj-cij.org/icjwww/idocket/imus/imuscr/ imus_icr2003-04_20030121.PDF [hereinafter Oral Arguments IV].

253. Id. at $2 \overline{2}$.

254. Id.

255. Concerning Avena and Other Mexican Nationals (Mex. v. U.S.), Feb. 5, 2003 (Order: Req. for the Indication of Provisional Measures) at para. 59, available at http://www.icj-cij.org/icjwww/ idocket/imus/imusorder/imus_iorder_20030205.PDF [hereinafter Ordcr]. 
executing any of its nationals, the ICJ indicated that, should circumstances warrant, it would extend the order of provisional measures to any other Mexican national nearing an execution date. ${ }^{256}$

Granting Mexico its request for provisional measures sends a strong preliminary signal on how the ICJ might view the merits of this case. In its previous order of provisional measures in the Breard and LaGrand cases, the ICJ stated that the United States should take "all measures at its disposal." 257 This allowed the United States to bow to federalism concerns and say that it could not order the Governors of Virginia or Arizona to halt an execution. In oral arguments, Mexico pointed out that this was in fact not the case, as both the U.S. Supreme Court and the Attorney General have the power to stop an execution or sue the states for violating a treaty obligation. ${ }^{258}$ However, the ICJ did not leave such an opening for the United States this time. The February 2003 order for provisional measures directs the United States to "take all measures necessary" to ensure that the Mexican nationals in danger of having their sentences carried out are not executed pending the decision on the merits of this case..$^{259}$

\section{B. A Suggested Outcome}

Mexico presented its arguments on the merits of the Avena case to the ICJ on June 20, 2003, with the United States scheduled to respond on November 3, 2003. A decision may not be forthcoming until late 2004 or early 2005. Therefore, this Comment will suggest a potential outcome of the ICJ deliberations.

In the LaGrand decision, the ICJ took a risk by saying that its provisional measures were binding despite significant authority to the contrary. ${ }^{260}$ The ICJ may be willing to go out on a limb again. If the ICJ makes a stronger statement about the kind of remedy the VCCR requires, it will have to confront the U.S. contention that this impermissibly meddles with internal domestic affairs and transforms the ICJ into a criminal appellate court. It will also have to confront the issue of what review and reconsideration mean in the VCCR context.

The United States has maintained that clemency satisfies the review and reconsideration requirement because those words require an exercise of judgment. It argued that even if review and reconsideration were provided in a judicial proceeding, a judge would still only exercise his or her own judgment. Therefore, the United States reasoned, it made little difference who exercised judgment, so long as someone did. In fact, the United

256. Id. at para. 56 .

257. Conccrning the Vienna Convention on Consular Relations (F.R.G. v. U.S.), June 27, 2001

(Order of Mar. 3, 1999: Req. for the Indication of Provisional Measures), supra note 109, at 1.(a).

258. Oral Arguments 1, supra note 230, at paras. 134-38.

259. Order, supra note 255 , at para. 59 (a).

260. See supra Part 11.C. 
States admitted that it was a "conscious choice to focus our efforts on clemency proceedings for providing the review and reconsideration" because clemency proceedings are "flexible" and "without procedural obstacles." ${ }^{261}$

The U.S. government has staked out the position that the ICJ went as far as it could permissibly go in its interpretation of the VCCR in LaGrand, such that any further pronouncements would constitute impermissible interference with domestic policies and internal governance. By emphasizing that LaGrand provided great latitude to craft the means of review and reconsideration, the United States implies that its discretion to implement this remedy is absolute. However, the ICJ rejected a similar U.S. argument in the LaGrand proceedings. In that case, the United States maintained that the ICJ could not even entertain Germany's arguments relating to the role of procedural default in U.S. courts, because to do so would call on the ICJ to "substitute its judgment for considered decisions of national courts in criminal cases" and thereby "improperly transform and expand the Court's role." ${ }^{262}$ The ICJ was not persuaded that a ruling implicating a domestic procedure would overstep its authority. Inasmuch as the ICJ has the authority under the VCCR and the U.N. Charter to delineate the "scope" of the VCCR, it may do so even where that judgment implicates domestic judicial proceedings. ${ }^{263}$

It is therefore likely that the ICJ will find that the United States has fundamentally misunderstood what the ICJ meant by review and reconsideration in LaGrand. Nowhere in LaGrand did the ICJ require "an exercise in judgment." The decision only required two things: review and reconsideration. Generally, the use of two words with different meanings implies two distinct and severable requirements. Following this reasoning, "review" mandates a complete examination of the record to determine the existence of VCCR violations and the circumstances in which they occurred. If this review locates a violation, then the second aspect of the remedy, reconsideration, would come into effect. Reconsideration, as the word is commonly understood, would mandate that the case be retried or reevaluated after discovery of the violation. The remedy might require any number of actions. It could require suppression of a confession because a consulate would have explained to defendant the right to remain silent; a new trial because the first trial was conducted without effective counsel and the consulate would have provided a better lawyer; or a new sentencing hearing because the first lacked mitigating evidence, and the consulate

261. Order, supra note 255 , at para. 37

262. LaGrand Case (F.R.G. v. U.S.), Mar. 27, 2001 (Written Pleadings: Counter-Memorial Submitted by United States of America) at para. 51, http://www.icj-cij.org/icjwww/idocket/ igus/igusframe.htm.

263. See LaGrand, supra note 2, at para. 52. 
would have provided information and witnesses from the defendant's country of origin. It is unlikely that the LaGrand court used two separate words to mean only one thing: an exercise in judgment, made by an elected official or hand-picked pardon boards. Thus, the United States may have to reconsider its position on this issue.

In addition, the U.S. remedy not only undervalues the words of the LaGrand decision, but also specifically permits subsequent violations to occur. LaGrand held that allowing the doctrine of procedural default to undermine the purpose of the VCCR was in itself a violation of the convention. LaGrand further held that whether the defendant was prejudiced by the violation was irrelevant to the determination of the violation and the obligation to provide a remedy. And yet, the review and reconsideration procedure formulated by the United States contradicts both holdings: it allows U.S. courts to apply a procedural bar to judicial review and to deny relief if it determines that the defendant was not prejudiced. If "review and reconsideration" is carried out like this, not only does the initial violation remain unremcdied, but two additional violations of the convention occur through the criminal proceedings.

Finally, the U.S. conception of review and reconsideration does not require even the limited "exercise of judgment" outlined above. At most, the United States has informed the ICJ that it will send a letter "requesting" review and reconsideration from state governors in each case where a VCCR violation has gone unanswered in judicial proceedings. In fact, the State Department's Legal Adviser specifically informed the ICJ that the State Department would not advise any U.S. court of the LaGrand requirement for review and reconsideration unless that court requested its opinion. ${ }^{264}$ Moreover, eighteen months after the ICJ's decision in LaGrand, the head of the government organization responsible for "formulating and implementing the foreign policies of the United States"265 maintained that U.S. courts were free to determine that "domestic law principles still preclude an express judicial remedy for a failure of consular notification."266

\section{Likely U.S. Intransigence}

Regardless of the outcome in Avena, the U.S. record with regard to its international legal obligations bodes poorly for the prospect of U.S. compliance. While governor of Texas, George W. Bush declared that the

264. Oral Arguments IV, supra note 252 , at 25.

265. Website of the Office of the Legal Adviser for the U.S. Department of State, at http://www,state.gov/s/l/.

266. Oral Arguments IV, supra note 252, at 25. 
VCCR did not bind Texas because Texas had not signed it. ${ }^{267}$ Therefore, it is not surprising that, in February 2003, Texas responded to the ICJ order for stays of execution of two prisoners by issuing a statement declaring that it was not bound by the ICJ order and would not halt the executions: "According to our reading of the law and the treaty, there is no authority for the federal government or this World Court to prohibit Texas from exercising the laws passed by our legislature,' said Gene Acuna, a spokesman for Texas [Governor] Rick Perry."268 The U.S. government has not yet said whether it will instruct Texas and Oklahoma to comply with the 1 CJ order. ${ }^{269}$

The Future of the Rights of Foreign Nationals: How to ENSURE U.S. COMPLIANCE WITH THE VCCR

Regardless of how the ICJ ultimately judges this dispute on the merits, the response of the federal government and the individual state executives will likely leave much to be desired. And, as discussed above, many state and federal courts seem to be unaware of or impervious to LaGrand, and in some cases unaware of the existence of the VCCR at all. ${ }^{270}$ However, one authoritative body has both the means to resolve this question and the authority to implement the result: the U.S. Supreme Court. In fact, Supreme Court precedent suggests that it should consider and enforce existing international legal obligations. The ICJ decision in LaGrand both created binding obligations on the United States and clarified international law. Enforcement of that law should and can be obtained through the judiciary.

\section{A. The Authority of International Law}

It has long been established that international law is incorporated into domestic law and must be enforced by domestic courts. In 1900, in the case of The Paquete Habana, the Supreme Court declared that "international law is part of our law, and must be ascertained and administered by the

267. See Amnesty Int'L, United States of America: Violation of the Rights of Foreign Nationals Under Sentence of Death, Jan. I998, at 2-3, http://web.amnesty.org/aidoc/ aidoc_pdf.nsf/Index/AMR510011998ENGLISH/\$File/AMR5100198.pdf.

268. C. Bryson Hull, Texas Snubs World Court on Execution Stays, ReUTERs, Feb. II, 2003 (quoting Gene Acuna), available at http://www.rense.com/general34/exce.htm.

269. Telephone Interview with Peter Mason, Office of the Legal Adviser, Consular Affairs, U.S. Department of State (Mar. 2I, 2003).

270. See, e.g., Report of the UN Special Rapporteur of the UN Commission on Human Rights, U.N. ESCOR, 54th Sess. at para. 120, U.N. Doc. E/CN.4/1998/68/Add.3 (1998). This report discusses the case of Mexican national Virginio Maldonado and reports that "the defense lawyer claimed a violation of the rights of his client under this treaty. According to information received, the trial judge stated, referring to the [VCCR]: 'I don't know that it exists . . I am not an international law expert." Id. 
courts of justice of appropriate jurisdiction, as often as questions of right depending upon it are duly presented for their determination."271 The VCCR, a self-executing treaty, was ratified by the U.S. Senate. ${ }^{272}$ As such, it is incorporated into domestic law and does not require any enabling legislation before courts can enforce the rights it creates. The problem with domestic judicial enforcement of the VCCR has been and continues to be confusion over what rights are actually created by the VCCR. Until this point, the Supreme Court has refused to answer that question clearly. However, the Court nced only look to its own precedent to ascertain that the ICJ decision in LaGrand enables it to settle the issue definitively for all domestic courts.

In Banco Nacional de Cuba v. Sabbatino, the Supreme Court held that "the greater the degree of codification or consensus concerning a particular area of international law, the more appropriate it is for the judiciary to render decisions regarding it, since the courts can then focus on the application of an agreed principle to circumstances of fact." 273 Sabbatino, standing alone, at most indicates that any decision rendered by an international dispute-settlement mechanism is evidence of an international consensus. However, with regard to the VCCR, the United States voluntarily ratified the Optional Protocol Concerning the Compulsory Settlement of Disputes at the same time it ratified the VCCR. ${ }^{274}$ Under the Optional Protocol, the United States agreed to submit all matters of "interpretation or application" of the VCCR to the compulsory jurisdiction of the ICJ. ${ }^{275}$ Ratification of this Optional Protocol to the VCCR makes it as binding as the terms of the treaty itself. ${ }^{276}$ At least one commentator has pointed out that the "inherently contractual nature" of treaties such as the VCCR demonstrates that the United States voluntarily chose to cede rcsolution of disputes to the ICJ and must be held to the terms of its bargain. ${ }^{277}$ Therefore, the "interpretation" of the ICJ (a tribunal to which the United States willingly deferred) creates "codification ... concerning a particular area of international law." 278 The Supreme Court can thus render an authoritative decision following both Sabbatino and the Optional Protocol to the VCCR.

271. 175 U.S. 677, 700 (1900). See also Restatement of Foreign Relations Law (Revised) $\S 131 \mathrm{cmt}$. d (Tentative Draft No. 6, 1985).

272. See supra notes $27-29$ and accompanying text.

273. 376 U.S. 398, 428 (1964).

274. See VCCR Optional Protocol, supra note 13.

275. Id.

276. See supra notes 30-34 and accompanying text.

277. Note, Too Sovereign But Not Sovereign Enough: Are U.S. States Beyond the Reach of the Law of Nations?, 116 HARv. L. REV. 2654, 2669-70 (2003).

278. Sabbatino, 376 U.S. at 428. 


\section{B. Procedural Default}

While the Supreme Court may thus find LaGrand influential, it is unclear to what extent the Court will adopt the ICJ's holdings. With regard to whether the VCCR gives rise to individually enforceable rights, the ICJ enables a simple clarification of a point that the Supreme Court already conceded was "arguably" the case. ${ }^{279}$ The Court may be less likely to adopt the ICJ's doctrine of procedural default and its approach to remedies.

The Supreme Court may be reluctant to import the ICJ's position on the doctrine of procedural default. While the Constitution makes clear that both statutes and treaties are the supreme law of the land, it is silent on how to resolve a conflict between them. ${ }^{280}$ However, the Court's own precedent demonstrates that it is the province of the judiciary to resolve conflicts between statutory and treaty obligations. In Breard, the Supreme Court applied the "last in time"281 rule to resolve this conflict. ${ }^{282}$ However, even where a federal statute vitiates the ability to enforce a treaty provision domestically, the international legal obligation of that treaty still exists, with all its foreign relations implications intact. As observed by former Supreme Court Justice Charles Evans Hughes when he was Secretary of State, "Congress has the power to violate treaties, but if they are violated, the Nation will be none the less exposed to all the international consequences of such a violation because the action is taken by the legislative branch of the Government." ${ }^{283}$ Courts, therefore, strive to avoid conflict where possible, especially when there is an absence of legislative intent to supersede a treaty obligation with a statutory one.

When faced with a treaty and statute relating to the same subject, the Supreme Court instructed "the courts will always endeavor to construe them so as to give effect to both, if that can be done without violating the language of either." ${ }^{284}$ Further, where Congress did not clearly evince intent to supplant a treaty obligation, courts have proven extremely reluctant to do so ${ }^{285}$ Nothing in the AEDPA or its legislative history mentions the VCCR ${ }^{286}$; thus, the Supreme Court should not interpret that legislation to supplant VCCR treaty obligations. Specifically, the Court should not

279. See Breard v. Greene, 523 U.S. 371, 376 (1998).

280. U.S. ConsT. art. Vl, cl. 2.

281. See, e.g., The Cherokee Tobacco Cases, 78 U.S. (1 Wall.) 616, 620-21 (1870) (holding that "[a] treaty may supersede a prior act of Congress, and an act of Congress may supersede a prior treaty" (citations omitted)).

282. Breard, 523 U.S. at 376.

283. DUNOFF ET AL., supra note 100 , at 45.

284. Whitney v. Robertson, 124 U.S. 190, 194 (1888).

285. See, e.g., United States v. Palestine Liberation Org., 695 F. Supp. 1456, 1464 (S.D.N.Y. 1988) (referring to The Chinese Exclusion Case, 130 U.S. 581, 599-602 (1889), and The Head Money Cases, 112 U.S. 580, 597-99 (1884)).

286. See AEDPA, Pub. L. No. 104-132 (1996) (codified as amended in scattered sections of 8, 15, $18,19,21,22,28,40,42,49$, 50 U.S.C., Fed R. APP. P. 22, and Fed. R. CIv. P. 32). 
read the AEDPA to extinguish completely a cause of action under the VCCR where it has found such a private, enforceable right to exist. ${ }^{287}$

\section{Remedy}

Finally, with regard to the question of remedy, the Supreme Court's own precedent again demonstrates that it is the appropriate body to fashion relief for VCCR violations. For example, in a 1998 Title IX decision, Gebser v. Lago Vista Independent School District, the Court discussed its ability to provide or deny a remedy under a federal statute. ${ }^{288}$ Where the cause of action was judicially implied, the Court held that it had "latitude to shape a sensible remedial scheme that best comports with the statute."289 In creating an appropriate remedy, the Court concluded that it should "examine the relevant statute to ensure that we do not fashion the scope of an implied right in a manner at odds with the statutory structure and purpose" of the legislation. ${ }^{290}$ The Supreme Court's power to provide a remedy for judicially implied rights in the statutory context is not diminished for rights created by international treaties.

Applying the principles set out in Gebser, the Court should look to the structure and purpose of the treaty and provide an effective remedy at law for violations of the VCCR. It is true that the ICJ recognized the necessity of allowing the United States to fashion the remedial scheme. ${ }^{291}$ But as Mexico pointed out in its recent presentation to the ICJ, the "wholly discretionary revicw" of executive clemency, conducted in secret and without standards by an elected official, would be "a poor substitute for the rights" provided by the VCCR. ${ }^{292}$

Under the U.N. Charter and the Restatement of Foreign Law, the United States is bound to comply with the decision of the ICJ. ${ }^{293}$ The existing conflict among circuit courts, especially with regard to the application of procedural default and the role of a prejudice standard, creates several certiorari-worthy issues. In fact, at least one Justice has openly expressed a desire to review the international aspects of these issues more fully. ${ }^{294}$ Such

287. See id. In United States v. Palestinian Labor Organization, 695 F. Supp. at 1468, the court held that the "later in time" rule requires "the clearest of expressions on the part of Congress." Therefore, "Congress' failure to speak with one clear voice" constrained the court to interpret the subsequent statute narrowly so as not to violate the preexisting treaty obligation. Id.

288. 524 U.S. 274 (1998).

289. Id. at 283.

290. Id.

291. See LaGrand, supra note 2, at para. 128.

292. Oral Arguments 1, supra note 230, at para. 98.

293. See 2 Restatement (ThiRD) of Foreign Relations Law, supra note 59, at $\$ 903 \mathrm{cmt}$. $\mathrm{g}$ ("Enforcement of judgments. Judgments of the [ICJ] are binding between the parties. 1.C.J. Statute, Article 59. Under Article 94(1) of the Charter of the United Nations, all members of the United Nations have undertaken to comply with a judgment of the Court in any case to which they are parties.").

294. Dissenting in LaGrand, Justice Breyer wrote that he would like more time to consider the "international legal issues involved." Federal Republic of Germany v. United States, 526 U.S. 111, 113 
a difference of opinion can only be addressed adequately by a national body like the Supreme Court. ${ }^{295}$

However, commentators observe that past ICJ decisions have had no more than a "persuasive force" on U.S. domestic courts. ${ }^{296}$ One recent decision even made reference to the conflict between the ICJ's interpretation of VCCR obligations and the precedent of the U.S. Supreme Court and found that it was constrained by its obligations to the latter. ${ }^{297}$ Therefore, an effective binding precedent for U.S. courts will come, if at all, through a Supreme Court decision.

\section{CONCLUSION}

More than eighteen months after the ICJ settled questions of rights under the VCCR, the United States was finally forced to announce its official position on that decision to the International Court. Now the ICJ will

(1999) (Breyer, J., dissenting). In Breard, Breyer also noted the international implieations of Breard's elaims in his dissent. Most significantly, Breyer pointed out that Breard's VCCR claims were of such a nature that, if aceepted, they might constitute a "watershed rule of criminal proeedure" sufficient to overcome procedural bars relied on by the majority. Breard v. Greene, 523 U.S. 371, 380 (1998) (Breyer, J., dissenting).

295. Although this Comment envisions an appeal by a foreign national as the vehicle to bring this issue before the Supreme Court, a recent note advocates that the Supreme Court exempt the VCCR from eurrent Eleventh Amendment jurisprudence and allow foreign governments to sue the offending U.S. state directly in federal court when state officials fail to notify foreign nationals of their VCCR rights. See Note, Too Sovereign But Not Sovereign Enough: Are U.S. States Beyond the Reach of the Law of Nations?, supra note 277 (observing that because of the expansive reading that eourts have given to the Eleventh Amendment, there exists no avenue open to foreign governments to have their grievanee against states adjudicated under our domestic judicial system). The note argues that where U.S. states also cannot be sued in the $1 \mathrm{CJ}$, this system makes states "too sovereign" in U.S. courts, yet "not sovereign enough" in the international dispute-settlement arena. If foreign governments could sue states in U.S. courts to vindicate treaty rights afforded by the VCCR, it is of course feasible that sueh an appeal would reach the Supreme Court, presenting that Court with an adequate opportunity to adopt the ICJ's interpretation of the VCCR.

296. See Mark Weisburd, International Courts and American Courts, 21 Mich. J. INT'L L. 877, $887(2000)$. However, recent decisions indicate that the Supreme Court may be growing more willing to heed the decisions of international tribunals. See, e.g., Linda Greenhouse, In a Momentous Term, Justices Remake the Law, and the Court, N.Y. Times, July 1, 2003, at Al (discussing the recent decision in Lawrence v. Texas, 123 S. Ct. 2472 (2003), and observing that Justice Kennedy's "citation of a 1981 gay rights opinion by the European Court of Human Rights, the first time a decision of that eourt has been invoked by a majority of the Supreme Court," was evidence of "the court's steadily growing interest in foreign legal developments"). In his dissent in Lawrence, Justice Scalia strongly criticized the majority's use of the European Court opinion, insisting that the Court "should not impose foreign views on American constitutional law." $123 \mathrm{~S}$. Ct. at 2495 (Scalia, J., dissenting) (quoting Foster v. Florida, 537 U.S. 990,990 n. (2002) (Thomas, J., concurring in the denial of certiorari)).

297. See United States ex rel. Madej v. Schomig, No. 98 C 1866, 2002 WL 31386480 (N.D. 111. Oct. 22, 2002), in which the district court explained the powerful role of the Supreme Court:

As Respondent points out and this Court acknowledges, it is extremely doubtful at this point that a federal habeas court could premise relief on a Vienna Convention violation. See 28 U.S.C. $\$ 2254$ (d) (limiting grounds of habeas corpus relief to violations of federal law "as determined by the Supreme Court of the United States."). It is for this reason, as much as any other, that this Court did not grant Petitioner relief on his Vienna Convention violation.

Id. at *2. 
have to evaluate whether the remedy that the United States has chosen to offer for its continuing violations of the VCCR satisfies its international obligations. Ongoing programs to educate law enforcement at the local and federal level are being carried out by the Bureau of Consular Affairs of the State Department, but these prophylactic measures are inadequate to fully protect VCCR rights. Regardless of how willing the ICJ is to dictate internal domestic procedures to the United States, the U.S. Supreme Court is in the best position to ensure that state and federal courts actually comply with the ICJ's interpretation of the VCCR. Therefore, the Supreme Court should import the rationale and reasoning of the ICJ, where that body has fully determined that domestic violations of the VCCR give rise to individually enforceable rights, remedies, and meaningful judicial review. 
